\title{
The Somatic, Premeiotic, and Meiotic Nuclear Divisions of Galtonia candicans.
}

\author{
BY \\ L. DIGBY. \\ With Plates LIX-LXIII. \\ INTRODUCTION.
}

THE cytology of Galtonia candicans has been the subject of much study, the large size of the nuclei, the clearness of the figures, and the low number of the chromosomes facilitating examination. Moreover, the tissues are easily 'fixed' and the nuclei take the stains readily. Notwithstanding these favourable features, there is yet much divergence of opinion as regards the sequence, and the interpretation, of the nuclear phases.

In 1904 Strasburger (30) described the heterotype divisions of Galtonia and concluded that the univalent chromosomes arose end to end in the spireme (telosynapsis), as previously described by Farmer and Moore (4) in various animals and plants. The following year (1905) Strasburger (31) changed his opinion and stated that the univalent chromosomes were arranged side by side in the spireme (parasynapsis). The meiotic phase was worked out in detail by Miyake (21) in the same year, and he corroborated Strasburger's second view. In I907 Mottier (22) endorsed Strasburger's original account as to the origin of the chromosomes. Grégoire (10) (1907), while agreeing with the parasynaptic chromosome formation, put a different interpretation on to the 'gamosomes' and 'zygosomes' of Strasburger and Miyake. These he believed were due partly to the action of the fixative and partly to the method of staining. In the course of this paper the different views held by these investigators will be discussed.

As Galtonia is easy to manipulate, and lends itself admirably to cytological study, it was suggested to me by Professor Farmer that it would repay further research.

In order to obtain a detailed knowledge of the cytology of Galtonia, it has been found expedient to examine the somatic, premeiotic, and meiotic divisions. The somatic divisions have been worked at in the roots. The divisions of the roots are far more easy to elucidate than are the premeiotic divisions of the archesporium, but those of the archesporium are instructive both from a comparative point of view and also for tracing the transition

[Annals of Botany, Vol. XXIV. No. XCVI. October, Igro.] 
between the premeiotic and meiotic divisions. The account of the somatic and premeiotic divisions will be followed by that of the meiotic phase.

The methods used have been described in a previous communication (3) and it is superfluous to repeat them here.

\section{Somatic and Premeiotic Divisions.}

One of the chief aims of this examination of the somatic divisions has been to ascertain the visible mode of transition from the telophase to the early prophase; that is, to follow the disorganization of the chromosomes and the gradual distribution of their substance throughout the nucleus, and to watch the ensuing reconcentration of their elements and their ultimate reorganization. In order the more clearly to demonstrate this demolition and reconstruction, the more usual plan of entering upon the cycle of nuclear division at the 'resting' stage has been abandoned for that of the metaphase; for at the metaphase one is confronted with tangible entities, whereas at the 'resting' stage one is dealing with a questionable and perhaps hypothetical structure.

\section{Metaphase.}

As the chromosomes go on to the spindle they may show every degree of longitudinal fission (P1. LIX, Fig. I). In some the split may have so far extended as to separate the daughter chromosomes widely; whilst in others it is merely to be recognized as a bright line in the substance of the chromosomes, and in others again it may be invisible, the chromosomes apparently being still homogeneous. This homogenity is especially characteristic of the chromosomes of the archesporium, for in these nuclei the longitudinal fission is often not seen until the chromosomes are about to separate on the equatorial plate. This character may be accounted for by the relatively larger amount of chromatin-staining substance in those cells which are to give rise to the germ cells. On the other hand, in the nuclei of the roots the longitudinal fission is much more precocious, and may be seen in the early spireme (Figs. 8 and 9). The cells of the pericycle show exaggerated fission as compared to those of the inner tissues (Fig. I2). This is probably due to the more rapid penetration of the fixing solution through the outer cells.

The nucleolus is drawn up on to the spindle in the confusion of the chromosome movement. It is deeply staining like the chromosomes, but can be recognized by its circular form. When the chromosomes have arranged themselves on the equatorial plate, the nucleolus is pushed off the spindle, and often appears to be repelled by a chromosome (Fig. I). It must finally fragment with amazing rapidity, as it is constantly to be seen when the chromosomes have but newly attached themselves to the fibres, but as they complete their equatorial arrangement, and as they separate and 
proceed to the poles, the nucleolus vanishes, and leaves no apparent trace of its existence. At the anaphase, the well-known and universally figured refractive brightly staining granules appear round the daughter nuclei, and about the zone of the remains of the spindle. Possibly these may be the remnants of the extruded nucleolus.

Strasburger (31) (1905) and Miyake (21) have shown the number of chromosomes in the somatic divisions to be sixteen. Of these, four are remarkably smaller than the remaining twelve, and in these twelve there is much range in size (Fig. 2). This characteristic difference is extremely well marked, and is always maintained throughout the generations. Unlike Tradescantia (5) (1905), whose roots show variable numbers in their chromosomes, Galtonia seems to keep persistently to its sixteen. Twelve counts of polar views of equatorial plates have been made, and of these, ten show diagrammatically sixteen chromosomes (Fig. 2); of the remaining two, one shows a possible seventeen and the other a possible fifteen. The larger number is probably due to the nucleolus having come into the field, the smaller number to the close approximation of two chromosomes which were consequently reckoned as one. The 'micro' or small chromosomes in a cross section of a spindle are always seen to occupy a central position (Fig. 2), as Wilson has figured in some Hemiptera (34) (1905, I).

The chromosomes attach themselves to the spindle by one end and for a short space of time they may lie horizontally, that is to say at right angles to the plane of the spindle (Fig. 3). The end of the chromosome which is attached is often bifurcated, and the split can be seen gradually extending to the free end (Fig. 3). As the split opens out, the chromosomes become drawn in on to the spindle, until they lie at full length on the fibres (Fig. 4). When the daughter chromosomes have nearly separated, each pair resembles a widely extended $\mathrm{V}$, the apex being the hump-like portion formed by the still joined ends of the daughter chromosomes (Fig. 4).

\section{Anaphase.}

As the chromosomes pass to the poles, they are long and rod-like and slightly hooked at their equatorially directed ends. The movements of the two pairs of microchromosomes are always in advance of those of the others ; they are the first to separate, and the first to arrive at the poles (Figs. 4 and 5), as in the Hemiptera (34) (1905, I). The microchromosomes are short and thick with rounded ends. The finest possible hair-like threads constantly connect the chromosomes when they are on the equatorial plate, and these threads can often still be seen when the chromosomes are passing to the poles, not only joining sister chromosomes but even chromosomes which apparently have no relation to one another (Fig. 5). These fine connexions arise from slight projections on the chromosome surface. As will subse- 
quently be shown these connexions are present throughout the prophases and originally united the linin (impregnated with chromatin) strands which will ultimately form the chromosomes (Figs. 8, 9, I0, and I3). Grégoire (9) (1906) describes and figures these connexions. Having reached the poles (Fig. I5), the chromosomes approximate closely and form a confused mass (Fig. I6). It is now that the above-mentioned refractive granules make their appearance, scattered in the cytoplasm round the daughter nuclei and around the spindle (Figs. I6, I7, and I8). A cell-plate is laid down midway between the nuclei (Figs. $6 \mathrm{~A}$ and $\mathrm{I} \eta$ ).

\section{Telophase.}

The chomosomes draw in their free ends and form a compact knot of relatively small size (Fig. I6). Then the knot tends to loosen out, but by this time the chromosomes have begun to lose their individuality (Figs. I7 and I 8). In some plants, as shown by Grégoire (9) (I906) and others, the chromosomes in the telophase become skeletons of their former selves. Their centre dissolves, leaving a space bounded on either side by thin threads. In Galtonia there is no such diagrammatic vacuolization of all the chromosomes, but it can be seen in parts. The chromosomes as a whole, by transverse division, break up into portions of various sizes, and these are distributed throughout the nucleus and are joined by fine connexions (P1. LXIX, Figs. 18, 19, and P1. LX, Fig. 20). At an early stage of chromosome disintegration either one or two 'chromatin' nucleoli are formed, evidently by the flowing together of the substance of portions of the chromosomes (Figs. 17 and 20). Nuclei with one or two nucleoli may be found throughout the prophases, but it has often been observed that those nuclei which start with but one nucleolus possess themselves of two, by direct division of that nucleolus. This happens in early prophase. The nucleolus becomes slightly indented, then hourglass-shaped, and finally breaks into two (Pl. LX, Fig. 29). This mode of duplicating the nucleolus has been previously figured and described by several investigators both in animals and in plants. The nucleoli, as a whole, in the somatic cells of Galtonia are not homogeneous, but show refractive spots or granules. As has been shown, the nucleolus persists until the metaphase, when it is cast out into the cytoplasm (P1. LIX, Fig. I).

Meanwhile changes have been proceeding in the cytoplasm. The portions of spindle fibres in the vicinity of the nuclei are the first to give place to reticulate cytoplasm, those nearer the equator remain for some time longer. Then the cell plate is gradually replaced by a definite cellwall (Figs. 6 A, 20, and 2I). Thus each daughter nucleus becomes an independent unit in its self-contained cell. Each cell is rich in cytoplasm of a fine reticulate nature. The character of the cytoplasm is modified according to the fixing reagents used. Fixed with strong Flemming 
it is soft and cloudy and finely reticulate; with acetic alcohol it is more coarsely reticulate; with Hermann it is stringy and becomes contracted in parts; with strong and medium chrom-acetic it contracts into dense flakes. Preparations fixed with strong Flemming and Hermann show indefinite areas of a dense deposit in the cytoplasm (Fig. I2). In some cases these areas stretch across the walls from one cell to another. Probably they consist of some oily storage material; they are not found in preparations fixed with alcohol and glacial acetic or with strong and medium chrom-acetic.

To return to the nuclear framework.

As the chromosomes break up, their fragments are seen to flatten out into viscous portions of linin (Figs. 6 A, 18, 19, 20, 21), in which the chromatin is carried in a diffuse state. In these nuclei there is no differentiation of linin areas and chromatin discs. The chromatic linin portions assume all manner of shapes and sizes, and strands are joined together by means of finely drawn out threads from the viscous substance. These threads persist throughout the prophases, and finally join the separate chromosomes. If it is remembered that the nuclear framework is of a colloidal nature, it is easy to imagine the variety of forms and shapes that might result. As the chromosome segments flatten out they may become alveolized; the central portion dissolves, leaving the sides as parallel threads (Fig. 2I); or large alveolar windows may appear in the linin (Fig. 19); or the linin may break up into small rounded particles which may lie parallel to one another (Figs. $6 \mathrm{~A}$ and 21 ). Whatever form the linin takes it is seen to stain uniformly. From this it may be concluded that it is impregnated with an evenly distributed solution of chromatin. In some nuclei pieces of homogeneous looking chromosomes may still be present, whilst the other chromosomes may have already broken up and be indistinguishable in the nuclear framework (Fig. 2I). In the roots of Allium Grégoire (9) (I906) has shown that each chromosome resolves itself into two parallel lines, composed of threads or granules. In the nuclei of the roots of Galtonia this parallelism is to be seen in parts of the linin, though in not nearly so diagrammatic nor in so regular a manner as in many plants. In the nuclei of the archesporium the linin is in a much more homogeneous and lumpy condition and shows comparatively little trace of parallelism. The linin breaks up into still smaller and smaller pieces, the parallel threads divaricate, and an irregular kind of meshwork results. The linin framework is at first more or less distributed throughout the nucleus, leaving a clear space round the nucleolus (Fig. 2I). The space becomes more emphasized as the nucleus approaches the so-called 'resting' stage (Fig. 6 B). Possibly the nucleolus may be exuding substances into the nuclear sap which effectually prevent any of the nuclear contents from encroaching on its vicinity. As the 
linin becomes finer and more granular, it is increasingly confined to the periphery. Hence, in order to ascertain the nature of the linin network, it is necessary to examine such sections of nuclei which are so cut as to show either the 'floor' or the 'roof', giving a broad view of the concave or convex surface of the network (Fig. 7). In sections through the centre of a nucleus the threadwork is shown squeezed against the nuclear wall. In such a view there must of necessity appear to be an abundance of parallelism in the threads as the sides of the meshes are seen in perspective. This is an easy source of error.

$$
\text { 'Resting' stage. }
$$

The chromatic linin framework continues to break up until a rough meshwork results. The finely drawn out linin threads now connect small rounded linin granules (Figs. $6 \mathrm{~B}$ and 7 ). The meshes of the network in some places may lie in strands, in others they appear stretched like a net. This is the nearest approach to a 'resting' nucleus. There is no real rest in the quickly dividing cells of a young root, or of the archesporium. These socalled 'resting' stages are not common in the roots and are still more rare in the archesporium. Strasburger (30) (1904) had difficulty in finding 'resting' nuclei in Galtonia. Possibly in some nuclei this stage may be omitted and they may pass on directly into the prophase. In the nondividing portions of the tissues, 'resting' nuclei with a far finer, almost cloudy looking, reticulum can be constantly found.

It is necessary here to make a slight digression and to mention curious crystalline looking bodies (Pl. LX, Fig. 28) which are often present in the nuclei of the two or three outer rows of cells of the root, and especially in the outermost row. They are apparently absent from the more quickly dividing cells of the centrally placed tissue. These 'structures' seem to be confined almost entirely to those nuclei which are 'in rest'. Leitgeb (15) found crystals in all parts of Galtonia candicans except in the underground portions of the roots and the bulbs. He described a vacuole round the crystals, and this vacuole might increase in size to so great an extent as to burst the nucleus, and the crystals were then projected into the cell lumen. He ascertained that the crystals gave a proteid reaction. Zimmermann (36) has described the presence of crystals in the roots, epidermis, and endosperm, \&c., of Ferns and Phanerogams. More recently Walker and Tozer (33) have figured nucleolar budding in the roots of Beans, and have shown that the buds pass out into the cytoplasm. In Galtonia these 'structures' apparently originate from the nucleolus. There may be one, or more, present in a nucleus. They are often crystalline in appearance and are of various shapes and sizes (Fig. 28). Some are like chips, some like blocks, some are oval. Sometimes they are split so as to appear double (Fig. 28c) and then closely resemble a small pair of chromosomes. In every case they 
take a chromatin stain, but slightly more faintly than does the deeply staining nucleolus. There is always a clear space round each crystalline body, and often one or more bright refractive dots are to be seen in close proximity (Fig. $28, b$ and $d$ ). In the isolated cases where the outer cells are dividing, the 'bodies' can be recognized throughout the prophase stages and are thrown out at spindle formation, as described by Zimmermann (36). Leitgeb (15) thinks that the crystals are probably reserve material, and that they are connected with the flowering of the plant, for he found that the further situated the tissue was from the bloom, the more sporadic the occurrence of the crystals.

\section{Prophase.}

Then follow an inverse series of events concerned in the building up of the chromosomes. The stages immediately following the 'rest' are not easily distinguished from those that precede it. The only recognizable criteria are, that in the prophases the nuclei are slightly larger, and there is a total absence of spindle remains.

The general object and character of the prophases is to compass a gradual and ever-increasing concentration of the linin until the completion of the fully formed chromosomes. The construction of each ultimate chromosome entails both an end-to-end joining of the separate linin fragments which have originated from the cross division of the chromosomes at the preceding telophase, and also a side-to-side approximation of the parallel longitudinal halves of each fragment which have arisen from the alveolization of the same. This early concentration may take diverse forms; the linin may be condensed into bands, or into irregular masses, or into granules (Fig. 22). All these variations may be found in a single nucleus. Again, these bands and masses may be homogeneous or vacuolized, and the granules may be scattered irregularly, or they may lie in parallel rows. In the roots these early stages are beautifully clear (Pls. LIX and LX, Figs. I9, 20, and 2I). There is a tendency for the reticulate nature to become modified, and for the meshes to be drawn into more definite strands. Each strand is ladder-like, its sides consisting of parallel rows of beads or granules which are cross connected by fine threads (P1. LIX, Figs. 8, 9, and IO), and fine threads also join the separate strands to one another (Figs. 8, 9, and I0). The strands become more definite. The fine thread-like connexions persist up to the time when the daughter chromosomes separate from one another on the spindle. Thus, except during anaphase and early telophase, the connexions are present throughout the nuclear cycle.

In Galtonia the chromatin does not lie in discs alternating with clear linin areas, but is equally diffused throughout the linin, giving a distinctly homogeneous appearance to the nuclear contents. 
At this stage there is still a definite concentration of the linin at the periphery (Fig. I8). As in the telophases, the prophases of the archesporium (P1. LX, Figs. 23, 24, and 25) show a far more decided massing of the linin into solid blocks than do those of the roots (Pl. LIX, Figs. 9 and I0). Concentration proceeds, and the parallel portions of linin, whether they be rows of granules or paired threads, gradually condense to form more homogeneous lengths of spireme (Pl. LX, Figs. 26 and 27). The space which formerly separated the parallel rows, as the sides approached one another, perhaps becomes the longitudinal fission which will eventually split apart the sides of the chromosomes (P1. LIX, Figs. 8 and 9) as suggested by Merriman (18). These stages in the formation of the somatic chromosomes have been beautifully shown by Strasburger (32) (1907) in the roottips of the Pea.

It is not easy to form a mental picture of what is actually proceeding in the nucleus during chromosome formation. Two opposite processes are at work. There is the shrinkage of the chromosome upon itself, and at the same time the preparation for the split.

From now onwards, there is a great increase in the stainable material, that is to say in the nuclein substances.

Grégoire in his paper on the somatic divisions of Allium, \&c. (9) (I906), has shown that the chromosomes may be formed in two ways. Either the chromosome band may keep its alveolar structure until it becomes a definite chromosome, and so retains a certain thickness throughout its formation; or the chromosome band may uncurl into a thin filament which forms a zigzagging spireme owing to the uneven concentration of the alveolar structure. In Galtonia these two types of chromosome formation are well seen. Strands of linin may be found whose granules, instead of lying in more or less parallel rows, are arranged in an irregular corkscrewlike way. As concentration proceeds a curling spireme results (Fig. II), the segments of which only straighten out during their final thickening prior to the evolution of the chromosomes.

\section{Chromosome Formation.}

No continuous spireme exists. As in the early prophases there is a great variety in the character of the linin framework leading to the formation of the chromosomes. In some nuclei the linin may be joined into lengths which are more or less polarized, whilst in others the linin is much fragmented (Pl. LX, Fig. 26), the separate portions being short and rounded, but of all manner of shapes and sizes. In either case the linin fragments, from being flat and ribbon-like, become thickened rods (Fig. 27). As their bulk increases, so does also their staining capacity. During this process of condensation the fragments gradually retreat from the nuclear periphery, and spread themselves across the nuclear cavity (Fig. 27). 
Gradually the individual fragments unite end to end until the typical and definite sixteen chromosomes can be identified.

Once more it is necessary to emphasize the fact that in the archesporial nuclei, the chromosome fragments are more or less homogeneous and show little sign of longitudinal fission (Fig. 27), whereas in the chromosome fragments of the nuclei of the roots (Pl. LIX, Fig. I2) the fission is most marked. As the chromosomes form, they lie somewhat polarized towards the nucleolus. The next stage shows them as definite entities, their sides still united by the delicate connexions (Fig. I3) which invariably arise from a slight protuberance. The difference in size of the chromosomes is most noticeable. In the roots the chromosomes often show bifurcated ends and the longitudinal fission throughout their length (Fig. I4), whilst others show only partial fission, and others complete chromatic concentration. The edges of the longitudinal fission are ragged. As has been already mentioned, the cells of the outer layers of the root show an exaggerated fission (Fig. I2). In exceptionally precocious cases the chromosomes may have split apart, forming the widely extended V's, even before the cytoplasm shows any radiations (Fig. $13, v$ ). As a rule the first signs of the radiations, which indicate the line of future stress of the fibres, appear when the chromosomes are distributed throughout the nucleus. The fibres push themselves into the nucleus, the nuclear wall by this time having disappeared, the chromosomes collect at the centre of the nucleus and pass on to the equatorial plate (Fig. I4). The spindle, which is composed of well-marked fibres, terminates bluntly at both ends (Fig. I). This completes the history of the cycle of the nuclear division.

\section{Conclusion.}

It will be gathered that this investigation supports the views held by Strasburger (30) (1904) and by Grégoire (9) (1906) as regards the story of the somatic divisions. Grégoire has shown that in the alveolization of the chromosomes during the telophase, the chromosome band resolves itself into two parallel threads with an intervening clear space. The spaces become obliterated owing to the separation and interlacing of the fine threads, and thus a network is formed. A nuclear rest ensues. As the nucleus passes into the early prophase, the network is transformed into 'bandes alvéoloréticulées ou spongieuses', which are identical with the alveolar chromosome bands of the telophase of the preceding division. By progressive concentration the bands become homogeneous chromosomes. There are no chromatic discs.

The somatic divisions of Galtonia follow the above summary of Grégoire in its general lines, and his plan can be adopted as the working principle. Nevertheless, these nuclei exhibit great variations, variations 
not only between nucleus and nucleus, but within the individual nucleus itself. The somatic division figures of Galtonia can neither be adequately illustrated by diagrams nor described 'by a rule of thumb'.

\section{First Meiotic Division.}

It has already been said that the archesporial divisions have been studied in order to watch the transition of the telophase of the last archesporial division into the early prophase of the pollen mother-cell. In this way a genuine comparison between the premeiotic and meiotic divisions can be obtained.

It is extremely difficult, if not impossible, to assert positively that any one particular telophase is that of the last archesporial division; and as a necessary outcome that its two component nuclei will become pollen mothercells. The archesporial nuclei in Galtonia do not divide synchronously. In a section of an anther before the differentiation of the pollen mother-cells, the archesporial nuclei are at all stages of division. These nuclei pass imperceptibly into the pollen mother-nuclei. There is no rest between the last stages of the archesporium and the differentiated pollen mother-cells, as is also the case in Hyacinthus orientalis (13). In the anthers of the very youngest buds that undoubtedly show pollen mother-cells, the majority of the nuclei will be seen to be in the very early prophase, whilst others have apparently only just divided and are still in telophase, and others again may be yet in late anaphase. No dividing line can be drawn between these stages. The nucleus proceeds, without interruption, on its course, and it is only by its general appearance that it becomes evident that it has passed through one phase and has entered upon the next.

Immediately on the differentiation of the pollen mother-cells, the anther increases in size. The cells therefore cover a larger area, and consequently the nuclei become more widely separated. In very young buds the pollen mother-cells of the inner whorl of anthers will be still small and closely packed together, having only just divided, while those of the outer whorl of anthers will already show a great increase in size both in cells and in nuclei. It is from these very young pollen mother-cells that the telophases have been taken as those of the last archesporial divisions.

\section{Telophase of the last Archesporial Division.}

Except for the fact that the nucleus is slightly larger in size, the telophase of the last archesporial division resembles in detail that of the somatic divisions (Pl. LX, Fig. 30). The chromosomes fragment transversely into portions of linin. There is much vacuolization in the chromosome portions, and much parallelism in the thin threads resulting from the vacuolization of the chromosomes. As in the somatic divisions fine con- 
nexions join the various fragments (Figs. 30 and $3 \mathrm{I}$ ). One or, sometimes, two nucleoli are formed. At first the nucleolus takes a chromatin stain, but it quickly changes this staining reaction and becomes a typical eu-nucleolus of a most colourless nature.

\section{Early Prophase of First Meiotic Division.}

Rapidly the cells of the anther enlarge, and the nuclei become more widely separated, and at the same time increase in size. A still finer fragmentation of the linin proceeds, resulting in the production of variously sized, rounded, and angled particles (Figs. $3^{\mathrm{I}}$ and 33). Many of these lie parallel to one another. A very common form is that of parallel rows of paired bead-like portions (Figs. 33, 36, and 37). These beads may be in single pairs, or several may be strung together by delicate threads. Each bead is convex on its outer, and straight on its inner, side. In the same nucleus in which some of the linin has thus finely fragmented, there may still be found large alveolized bands of chromosomes consisting of a broad strip of linin showing a clear centre (Figs. 34 and 35). As in the somatic divisions the chromatin appears to be diffused throughout the linin. There is a uniform staining capacity.

Meanwhile the nuclear framework tends to withdraw to the periphery, leaving the nucleolus in a more or less clear space in the centre (Fig. 36). Owing to the increase in size of the nucleus and to its peripherally arranged framework, the nucleus now appears to be emptier than at an earlier stage of prophase. Especially in a thin and superficial section (Fig. 35) of the framework, striking examples of vacuolization in the linin fragments, and of parallelism in the threads, are to be seen. As in the somatic prophases a net-like arrangement of fine connexions joins these fragments to one another. There is no limit to the variety of forms which the linin portions may adopt, but throughout there is a general impression of parallelism in the linin threads, or portions of threads, and of vacuolization in the less segmented chromosome strands. These strands which show vacuolization are portions of chromosomes which have retained their entirety to a comparatively greater extent, and whose sides have not yet separated.

Thus except for the size of the nuclei the somatic and the early heterotype prophases closely resemble one another, and, as will be subsequently shown, the homotype prophases are also similar. The parallel portions in both represent longitudinal halves of somatic chromosomes, and are probably the sister halves of the same chromosome, which are now severally coming together and condensing to form the somatic or univalent chromosomes.

From here onwards differences in the two types of division occur. In the somatic divisions the parallel paired portions of the chromosomes become more and more condensed to form each single univalent chromo- 
some, but in the heterotype, prior to the formation of the bivalent chromosome, the synaptic stage is intercalated.

The linin becomes more and more confined to the nuclear periphery, and this causes an exaggerated appearance of parallelism as in the case of the somatic divisions (Fig. 37). Gradually the linin becomes contracted into more lumpy portions joined by the fine threads, which often run parallel to one another and crosswise (Figs. $3^{8 \mathrm{~A}}$ and $3^{8 \mathrm{~B}}$ ). Once more the linin tends to become distributed throughout the nuclear cavity (Pls. LX and LXI, Figs. 39A and 40 ). This is the definite beginning of the first contraction. The massing increases, the fine threads becoming obliterated in the general confusion though their double character is still marked (Figs. 39A, 39 B, and 40). 'Chromatic' bodies (3) may be extruded at this stage. The linin begins to collect at one side of the nucleus (P1. LXI, Fig. 4I) until gradually the whole nuclear framework is drawn into the knot, which is balled together at one side of the nucleus (Fig. 43). Thus it seems clear that in Galtonia the parallel and sometimes fused linin portions which enter the synaptic knot as a general rule represent the concentrating sides of a single somatic chromosome, and not the approximation of two somatic chromosomes as described by Grégoire (10) (1907) and other workers in the heterotype prophases of animals and plants. As the parallelism found in the early heterotype prophases has the same appearance and the same origin as the parallelism found in the somatic prophases, it seems inconsistent to hold that in the heterotype prophases each parallel side represents a length of a whole somatic chromosome, and that in the somatic prophase each parallel side represents a length of half a somatic chromosome. It is true that there is so much variety in the thickness of the linin portions and so much general irregularity that it would be impossible to determine the significance of any specified parallelism. It is only by taking a broad and comparative view of the heterotype prophases in relation to the somatic prophases that one is forced to admit that the parallelism of the one is homologous with that of the other. Moreover, if the nuclei of the surrounding tapetal cells (Pl. LX, Fig. 32) are compared with those of the pollen mother-cells there will be seen to be equally striking parallelisms present.

If this interpretation of the parallelisms in the presynaptic stages of Galtonia be correct, then the presence of parallel threads in the prophases of parthenogenetic eggs would be explained (19) (1907).

The parallelism in Galtonia is not so diagrammatically evident as figured in many plants. Though it may be said that the majority of the nuclear prophases of the pollen mother-cells do show parallelism to a greater or less degree, nevertheless nuclei can be frequently found in which the linin is of a more concentrated nature and no parallelism is apparent. 


\section{Synapsis.}

The nucleus lies excentrically in the cell (Pl. LXI, Fig. 43), the chromatin mass being always on the side of the narrow strip of cytoplasm (Fig. 43). The spherical nucleolus, more or less hidden by the chromatin, projects into the clear nuclear cavity (Figs. 42 and 43 ). In some cases two nucleoli are present. There is no definite nuclear wall, the nucleus is bounded by cytoplasmic fibrils, and this continues throughout the subsequent stages, a wall only reappearing at the anaphase.

There is an important difference between this account of the presynaptic and synaptic stages of Galtonia and that given by Miyake (21). He describes the massing of the chromatin in the presynaptic stages into 'zygosomes'. The zygosomes are double; the halves each represent a somatic chromosome. They collect in synapsis and retain their individuality. When the knot loosens the chromatin from each zygosome streams into a thread and thus forms the double thread of the spireme. Each thread represents a univalent chromosome. Zygosomes have not been seen in these preparations. Throughout the presynaptic stages there is a doubling in the arrangement of the chromatin, but the chromatin is present in the form of variously sized and shaped portions; there is no concentration into definite centres. With prolonged staining with Heidenhain, followed by much decolorization, darkly staining patches can be distinguished in the synaptic knot, as Grégoire (10) (1907) has described in his observations on Galtonia ; but, as he points out, these appearances are solely due to excessive differentiation in which all control of the stain has been lost. Sometimes in a favourably stained slide it is possible to distinguish a linin matrix in which irregular chromatin masses are embedded (Fig. 42); but as a rule the knot, at close synapsis, stains practically uniformly and resembles a heap of tightly compressed blocks in which no structure can be seen (Fig. 43). Thus synapsis in Galtonia faces one as an impenetrable wall. Great and far-reaching changes and rearrangements are possibly proceeding, but any suggestion as to their nature can be but merely speculative.

The synaptic stage is one of long duration, judging from the frequency with which it is found. At synapsis the pollen mother nuclei of all the anthers of a bud may be found to be at this stage, whereas before synapsis, and especially after synapsis, there is an extensive range in the nuclear phases in the anthers of a single bud. For example, one anther may show its nuclei to be entering on the 'open spireme' stage, whilst the nuclei of another anther may have fully formed chromosomes. Or, again, one anther may have its nuclei in 'diakinesis' preparatory for the heterotype division, whilst the nuclei of another may be completing the homotype division. There is also a considerable difference in the progressive nuclear stages, not 
only between the four lobes of a single anther, but also in each individual lobe itself.

During synapsis the 'chromatic bodies' as described by von Derschau (2) are thrown off in abundance (Figs. 42 and 43). There is at this time a great increase in size of the anthers. The contained pollen mother-cells begin to separate from one another. Details concerning the extrusion of the 'chromatic bodies' and the rounding off of the cells have already been given (3).

\section{Hollow Spireme.}

Prior to coming out of synapsis the knot loosens. Shavings of a knot at this stage show it to consist for the most part of irregular masses of chromatin. These masses may occasionally be broken up into smaller granular portions. The knot unravels, and its substance emerges in the form of loops or strands (Fig. 44). Some of these may be more or less ribbon-like (Fig. 44), whilst others may be formed of large beads strung together (Fig. 45); some may show marked longitudinal fission (Fig. 45), whilst others may be homogeneous (Fig. 46). Lengths of spireme may be thick for a certain distance, and then their sides may divaricate widely (Fig. 48) and join other strands; others may be very delicate and anastomose freely and show no order which could be co-ordinated into a scheme. This great irregularity has been emphasized by Maréchal and Saedeleer (17).

In Galtonia it is evident from subsequent events that the spireme at this stage is univalent in nature, that is to say that it represents lengths of single somatic chromosomes as described by Farmer and Moore (4), and not lengths of paired somatic chromosomes as described by Grégoire (10) (1907); consequently that the fission in the threads is homologous with the parallelism found in the presynaptic stages and in the somatic prophases; further, that this fission will ultimately divide each univalent chromosome into two daughter chromosomes at the second meiotic division, and will not separate two univalent chromosomes at the first meiotic division. As will be shown, in Galtonia the homologous lengths of spireme do eventually fuse into thick bivalent strands (Figs. 53 and 54) which split apart, after second contraction, into their two component chromosomes (P1. LXII, Figs. $5^{8 \mathrm{~A}}$ and $5^{8 \mathrm{~B}}$, \&c.). Although it is only at a later stage that the univalent strands pair, yet when the spireme emerges from synapsis there are already indications of the joining together of lengths of homologous spireme. The thick loops (P1. LXI, Fig. 44) are striking examples of a telosynaptic union of univalent chromosomes. At the end of the loop there is often a swelling to be seen as if the junction of the two homologous lengths of spireme, each of which will be a univalent chromosome, caused some physiological disturbance. The sides of the loops are sometimes beaded (Figs. 45 and 46), sometimes they are more homogeneous (Fig. 44), 
but in either case they closely resemble the univalent chromosomes when they have but newly separated after second contraction, and are still united at one end (Pl. LXII, Fig. 6I). The univalent lengths of spireme may show every degree of union with their homologous pair. They may, as has been shown, be arranged end to end (Pl. LXI, Fig. 44), and certainly at a slightly later stage they may be joined side by side (Figs. 52 and 53), and there may be every intervening degree of connexion between these two extremes. Or they may yet be entirely independent one of the other. Although the secondary union of the individual strands is ultimately achieved, each strand is primarily univalent, and it is only by a bending over and fusion of univalent lengths that the bivalent segments are formed.

Thus it appears that the parallel portions of linin which entered the synaptic knot, and represented the condensing longitudinal halves of sections of somatic chromosomes, have, during synapsis, become concentrated and joined end to end to form lengths of whole somatic chromosomes. The concentration is not always complete, for the space between the longitudinal halves reappears in the post-synaptic stages as longitudinal fission. Further, that during synapsis the rearrangement may have been still more extensively elaborated, and that the homologous univalent lengths of spireme may have joined in pairs (Figs. 44 and 45). Overton (24) (I909) has stated that during synapsis there may not only be a conjugation of parental chromosomes, but also 'an actual interchange of influence'.

As the loops and strands come out of synapsis they distribute themselves throughout the nuclear cavity (Figs. 46 and 47). Their anastomosis and coiling is most intricate. Sometimes the spireme lengths appear to be joining end to end (Fig. 5I). Sometimes for a distance they are united side by side (Fig. 49). The nucleus then moves to the centre of the cytoplasm which surrounds it (Fig. 5I). The nucleolus has generally by this time returned to the nuclear boundary (Figs. 46 and 47). There it may remain throughout the subsequent stages until its final dissolution at diakinesis (Pl. LXII, Fig. 64), or it may be carried out by the spireme as it emerges from synapsis, and then take up a central position in the nucleus (P1. LXI, Fig. 52). During the loosening of the knot it sometimes stains for a time chromatically (Figs. 46, 47, and 48), but when the 'hollow-spireme' stage is reached, it once more becomes colourless (Figs. 49, 5I, etc.).

The nuclei of the 'hollow-spireme' stage again show every degree of variation. In some the loops and strands may consist of beads of chromatin (Fig. 47), in others they may be more ribbon-like (Fig. 49). Possibly this apparent difference in the composition of the spireme may be partly accounted for by the greater or less strain exerted on the nuclear contents. Again, the loops may lie more or less freely in the nuclear cavity (Fig. 47), or there may be an intricate anastomosis (Fig. 48). The anastomosis shows that the combinations necessary for the formation of the bivalent chromo- 
somes are still incomplete. The spireme may show every possible degree of longitudinal fission (Figs. 48 and 49) or of homogeneity (Fig. 47). Again the great range of degree of thickness of the various lengths of spireme as shown by a single nucleus must be emphasized (Fig. 49). Grégoire (11) (1910) has written that 'on ne constate que deux épaisseurs de filaments, celle des filaments leptotènes, et celle des anses pachytènes, double de la première'. This statement cannot be said to apply to Galtonia. Throughout, one is constantly reminded of the decidedly viscous composition of the nuclear contents, and that the threads may consequently be pulled out to any degree. Thus the comparative thickness of the threads seems to be an unstable foundation on which to build any hypothesis as to their real structure.

The spireme may prepare for second contraction as soon as it has come out of synapsis. In that case its loops leave the periphery and concentrate towards the centre of the nucleus. Such a precocious commencement for second contraction is shown in Fig. 52, where the sides of the loops are being drawn in parallel to one another and in some cases have already joined to form a thick strand. When an interval elapses between the contractions, the spireme goes through a phase of a straightening out of its segments (Figs. 49 and 50 ). In this case the anastomosing connexions gradually give way and the spireme segments are converted into more or less beaded strands showing longitudinal fission. Some of the spireme segments are generally in contact with the nucleolus, towards which they show a slight orientation (Fig. 50). Delicate hair-like strands connect the different segments and portions of the same segments to one another. Often whilst still in 'hollow spireme' there is a concentration of the chromatic strands in one or more places to form a mass of chromatin which has the appearance of a 'chromatin' nucleolus.

\section{Second Contraction.}

The beginning of the second contraction is marked by a drawing in of the loops and strands towards the centre of the nucleus (Fig. 54). At the same time there is a concentration of the univalent lengths to form the thick bivalent segments (Fig. 52). This is accompanied by a loss of their beaded appearance and a considerable increase in their staining capacity (Fig. 53). Although the chromatin segments become confused and indistinguishable in the conglomeration, yet there is no such absolute obliteration of the course of events as in the first contraction. Usually some portions of loops, or strands, escape from the central mass, showing the parallel univalent strands (Pl. LXII, Fig. 55). The nucleus at this stage has decreased in size.

It seems possible that, during synapsis, the lengths of univalent chromosomes are sorted out, and that during the second contraction the pairing of these homologous lengths of spireme is completed. 


\section{Chromosome Formation.}

In Galtonia the evolution of the eight bivalent chromosomes from the apparent chaos of the second contraction is very clearly demonstrated. Sometimes, as the second contraction loosens, the limits of the eight bivalent chromosomes can be identified each in the act of splitting into its two univalent chromosomes (Fig. 57). This split separates the univalent strands which became united during the preceding stages. It must not be confused with the true longitudinal fission in the substance of each univalent chromosome which is the homologue of the somatic fission. The real longitudinal fission is to be seen in the loops of Fig. 56, each side of which represents a univalent chromosome, the two chromosomes being independent of one another except at their extremity. In many cases the second contraction mass of chromatin separates out into large oval or rounded blocks, often joined end to end like a string of beads (Fig. $5^{8} \mathrm{~A}$ ), in which the limits of the individual chromosomes are at first not discernible. Then a splitting of these bivalent homogeneous blocks takes place (Fig. $5^{8}$ B). Whatever the shape and length of the segments, whether they are joined together by fine threads, or whether they are more isolated, a fission is to be seen gradually splitting them apart into somewhat flattened ribbon-like pieces with ragged edges (Fig. $5^{8}$ B). These at first stain faintly, and are visibly of a different constitution to the unsplit segments. Thus by degrees the outline of each pair of univalent chromosomes is identified. Very quickly they become concentrated, assume an entire outline, and stain deeply and homogeneously. So soon does the concentration follow on the split, that the part that has already split is noticeably more deeply staining than the portions that are in the act of splitting (Figs. $59 \mathrm{~A}$ and $59 \mathrm{~B}$ ). Where the segments are joined as a string of beads, they split independently of one another, and then the split portions of either side close up end to end (Figs. 57 and 59 B), recalling the origin of the somatic chromosomes.

All stages of this splitting apart can be seen, but apparently it is a phase that is quickly passed through. Whilst the nuclei of one anther lobe may show the actual splitting phenomena, the nuclei of the adjacent lobe may have fully formed, thick, contracted chromosomes. As the split proceeds, the sides divaricate (Figs. 60 and 61 ), and each represents a univalent somatic chromosome.

Immediately on the separation of the two parts, representing univalent chromosomes, the original longitudinal fission may be recognized in the substance of each one (Figs. 59 B and 60). This fission was prepared for in the presynaptic stages by the condensation of parallel threads which represented sister sides of a single somatic chromosome (Pl. LX, Fig. 35, etc.). Though lost to sight during synapsis, the fission which reappeared in the lengths of univalent spireme as it emerged (Pl. LXI, Fig. 45) is believed to 
bear the same significance as the fission present before synapsis. The fission could again be recognized in the loops as they escaped from the second contraction (Pl. LXII, Fig. 56). It will finally divide each univalent chromosome into the two daughter chromosomes in the homotype division (P1. LXIII, Fig. 75). The fission is only to be seen for the extremely short interval when the newly differentiated univalent chromosomes are still flattened and uncondensed (Fig. 59 B). As soon as they are concentrated and rounded, the split is once more obscured to reappear in Galtonia as the chromosomes approach the poles (P1. LXIII, Fig. 68).

The two individuals which constitute each bivalent chromosome may break apart at once, or they may remain for a time joined at one end, so as to form a loop (Pl. LXII, Figs. 60 and 6I). Often, in such loops, one limb is seen to be composed of homogeneous chromatin, whilst the other limb consists of large chromatin beads (Fig. 6I) alternating with linin areas, the chromatin not having yet concentrated. This is strikingly like the figures of King (14) in Bufo, except that in Bufo each chromatin portion represents a single univalent chromosome, and the intervening faintly staining areas the points of future transverse cleavage between the chromosomes.

When the segments have but newly split, it is possible to identify the eight pairs of chromosomes (Figs. 57 and 60). Apparently the large pairs of chromosomes are joined to form long loops (Figs. 60, 61, a nd 62). The individual chromosomes are attenuated (Fig. 60) as compared to their appearance in the later stages (Fig. 62). The two pairs of small chromosomes are always in advance of the others. They are the first to be isolated from the second contraction (Figs. 55 and $5^{6}$ ), the first to split apart (P1. LXI, Fig. 53), and the first to become concentrated (P1. LXII, Fig. 60). When differentiated they are often in the form of a single sausage-shaped mass, which splits into a pair of somewhat bean-shaped chromosomes (Figs. 56, 59 B, and 60). One or other of the small pairs is nearly always in contact with the eu-nucleolus (Figs. 62 and 63 ). Wilson (34) (1905, I) has shown that the larger idiochromosome in Lygaeus bivalens and the accessory chromosome in the Hemiptera $(35)(1905,2)$ are in the same way attached to the plasmosome. Stevens (29) in Trirhabda has found a similar association in the case of the irregularly paired heterochromosomes.

On the differentiation of the eight pairs of chromosomes there is a rapid concentration and thickening of the individuals (Figs. 62 and 63 ). The members of each pair always remain close to one another. Strands of linin traverse the nucleus. Sometimes one or more of the pairs may be connected to form a chain (Fig. 63) as in Tradescantia (22) and Oenothera (1). Before diakinesis the chromosomes become much contracted and are very thick, and stain densely. The small chromosomes are usually round, the larger ones are more rod-like (Fig. 64). Then the nucleolus fragments 
(Fig. 64), the chromosomes contract to their extreme limit, move to the periphery of the nucleus, and enter the well-known diakinesis stage. At the same time radiations appear in the cytoplasm (Fig. 64). As already described by Miyake (21) the spindle has a multipolar origin and gradually becomes bipolar.

This description of the origin of the univalent chromosomes of the first meiotic division agrees fundamentally with that of Strasburger in I904 (30) and of Mottier (22). In 1905 Strasburger (31) and Miyake (21) both concluded that the spireme as it comes out of synapsis is bivalent, and that the two univalent chromosomes are formed by a separation of the two longitudinal halves of the spireme. In this investigation it has been concluded that the spireme is univalent, and that the univalent strands only join together secondarily to form the bivalent lengths which finally split apart into the univalent chromosomes.

\section{Spindle Figures.}

The fibres push their way into the nucleus, and the chromosomes collect on the spindle (Fig. 65). The entire univalent chromosomes of each pair move off one to either pole (Fig. 67). A polar view of the equatorial plate shows the great variety in size of the chromosomes; the two small ones usually take up a central position (Fig. 66). As the chromosomes approach the poles the longitudinal fission is once more to be seen (Pl. LXIII, Fig. 68). The halves may separate widely so as to form V-shaped figures (Fig. 68). The polar view of an aster shows the eight chromosomes longitudinally split (Fig. 69). Again the small ones are centrally placed (Fig. 69).

\section{Anaphase.}

Arrived at the poles, as in the somatic divisions, the chromosomes at first form a condensed mass (Fig. 70). Then they separate out, fragment, and the fragments become alveolized, showing 'windows' and parallel threads (Fig. 7I). One or two nucleoli appear, and a nuclear wall surrounds the daughter nuclei. At the same time a cell-plate is laid down at the equator of the spindle (Fig. 72). The refractive granules in the cytoplasm round the nuclei and about the spindle are obvious (Fig. 72). Thus imperceptibly the anaphase leads into the telophase (Figs. 70,71 , and 72 ).

\section{Telophase.}

The telophase of the first meiotic division is precisely like that of the somatic divisions (Figs. $7 \mathrm{I}$ and 72 ). There is the same fragmentation, and the same alveolization of the fragments resulting in parallel threads (Fig. 73). The linin, as a whole, does not break up into such fine portions as in the somatic divisions, but remains in rather large fragments, as usual united by fine threads. There is no resting stage. Thus the telophase of the heterotype passes into the prophase of the homotype (Fig. 74). 


\section{Second Meiotic Division.}

\section{Prophase.}

The first indications that the nuclei have entered upon the reconstructive prophase stages are the disappearance of the spindle fibres and the reconcentration of the linin portions (Fig. 74). The nucleolus, which when first formed in the telophase of the heterotype was of a chromatic staining nature, has by now become cytoplasmic in staining reaction. No nucleolar budding or 'body' formation has been observed in the homotype divisions. The nucleolus remains spherical and colourless, and is apparently ejected into the cytoplasm as the chromosomes collect on the spindle.

Once more the halves of the concentrating portions of the linin come together, and there are striking cases of concentration to be seen, just as in the somatic and presynaptic prophases (Figs. 75 and 76). Meanwhile the cell-plate has given place to a clear wall which divides the two daughter nuclei, and which is continuous at either end with the circular enveloping wall (Figs. 75 and 77). The nuclei elongate at right angles to the plane of the heterotype spindle (Figs. 75 and 77). At the same time definite spindle fibres appear in the cytoplasm (Figs. 75 and 77). They focus more or less to a point at either end, and widen out as they approach the extremities of the nucleus. Concentration of the segments proceeds. There are still small, flat, angled portions of linin, but they tend to become more and more individualized (Figs. 75 and 76). They are connected by fine threads. Gradually the segments join on one to the other (Fig. 77). Sometimes longitudinal fission can be seen in them, but generally they are ribbon-like and more or less homogeneous (Fig. 77). At a later spireme stage the chromatin contents are drawn out into long strands, which lie in the plane of the elongated narrow nucleus. These strands may lie massed together and be interwoven so as to form an almost undecipherable tangle. The spindle fibres enter the nucleus and penetrate the tangle (Fig. 78). The nuclear wall has meanwhile gradually disappeared.

\section{Metaphase.}

Then the chromosomes become differentiated, and take up their position on the equatorial plate (Fig. 79). At first they are still long and, lie somewhat in loops and curves (Fig. 78), but when they have completed their equatorial arrangement they contract considerably, and consequently shorten and straighten (Fig. 79). Their outer ends become bifurcated, and, contrary to the direction in the somatic divisions, the split apparently proceeds inwards. The spindle fibres usually focus to a sharp point at either end (Fig. 79). The two nuclei generally (if not always) divide parallel to 
one another, at right angles to the plane of the heterotype division (Figs. 79 and 80). As the chromosomes separate they again contract (Fig. 80), but become elongated as they near the poles (Fig. 8I).

\section{Diaster.}

The chromosomes of the four daughter nuclei often arrive simultaneously at the poles (Fig. 8I), but sometimes one nucleus may be in the diaster stage, whilst the other is still in the metaphase.

\section{Telophase and Anaphase.}

The telophase resembles that already described in the somatic and first meiotic divisions. There is the same alveolization of the chromosomes, followed by a breaking up of the longitudinal halves into more or less beaded portions which are distributed throughout the nuclear cavity and are connected with one another by fine strands (Fig. 82). Each nucleus of the tetrad gradually rounds itself off and becomes independent of the others. The anaphase passes into the 'resting' stage (Fig. ${ }_{3}$ ).

\section{'Resting' Nucleus and Pollen Grain.}

The cytoplasm round the 'resting' nucleus becomes vacuolated. The linin contents may be in the form of granules showing often a double linear arrangement (Fig. 83), or they may be in larger lumps exhibiting definite traces of parallelism representing the remains of the alveolized portions of the chromosomes of the telophase.

Thus the 'resting' nucleus of the tetrad upholds the principle of irregularity so strikingly characteristic of all the divisions of Galtonia. The chromatin is here scattered throughout the nucleus, and thus is exactly opposed in arrangement to that described by Overton (24) (I909) in Thalictrum purpurascens, and by Rosenberg (26) (1909) in Crepis virens, where the chromatin in the resting pollen-grain nucleus is definitely aggregated into prochromosomes corresponding to the reduced number.

Then each nucleus with its cytoplasm passes through those changes relative to pollen-grain formation.

\section{General Considerations.}

One of the controversial questions which the study of Galtonia reopens is the significance of the parallel threads and linin masses in the heterotype prophases. In Galtonia it is believed that the parallelisms in the somatic, premeiotic, and meiotic nuclear prophases are all homologous, and in each case that they represent the approximation and concentration of the two longitudinal halves of portions of somatic chromosomes. This conforms to Strasburger's (30) (1904) theory as to the origin of the somatic 
chromosomes in Galtonia, but his (31) (1905) and Miyake's (21) interpretation of the parallelisms in the heterotype prophases is very different. They hold that the chromatin in the reticulum of the early heterotype prophase becomes concentrated into masses, 'gamosomes', which correspond in number to the somatic chromosomes. The 'gamosomes' before, and during, synapsis pair to form 'zygosomes'. From each 'zygosome' arises a pair of threads, the 'gamomites'. The 'gamomites' join and become 'zygomites'. The 'zygomite' splits into its two component 'gamomites', each 'gamomite' being a univalent chromosome. In this investigation the 'zygosomes' have been interpreted as the concentrations of the longitudinal halves of the somatic chromosomes. Moreover no conclusion could be drawn as to the constancy in number of these concentrations. They appear to be quite irregular in form and in arrangement. Mottier (22) has found no correlation between the chromatic aggregations and the unreduced number of chromosomes.

Nearly all cytologists agree as to the presence of parallel threads and linin masses in somatic prophases. Strasburger $(30,32)$ (1904, 1907) has described them in the somatic cells of Galtonia and in roots.

Grégoire (9) (1906) has shown that in the telophases of the roots the chromosomes become alveolized; that the two sides of each chromosome separate widely and cross one another, forming a rough network; that when the nucleus enters upon the prophase, and the chromosomes have to be reconstituted, the network is transformed into 'bandes alvéolo-réticulées ou spongieuses', which are identical with those of the telophase; and that finally by concentration the bands become transformed into definite chromosomes.

Farmer and Moore (4) (1905) have figured and described parallelisms in the somatic cells of Periplaneta. 'At first the cells which are preparing for division present an almost even granulation of the chromatin within their nuclei, and this in its consistency strongly suggests a foam structure of the ordinary type ; but after a time the "chromatic confusion", as it were, sorts itself out into obvious condensations or cloudy areas, and it is apparently unquestionable that each of these primitive chromatic clouds is individually the forerunner of one of the future chromosomes.'

Many writers go a step further and believe that each of these condensations represent a somatic chromosome, and hence call them 'prochromosomes'. Rosenberg (27) (I909) has found in Nuphar luteum, Helianthus peploides, and several other plants, that prochromosomes are present in the resting somatic cells in the somatic chromosome number.

Overton $(23,24)$ (1905 and 1909) has stated that in the somatic cells of Thalictrum purpurascens there are forty-eight paired prochromosomes, and in the young pollen mother-cells there are twenty-four.

Sufficient evidence has been quoted to show that there are generally 
considered to be parallel threads and parallel aggregations of linin in the somatic cells. Further, that these parallelisms are the condensations of the sides of somatic chromosomes, whether of portions only, or of whole chromosomes. Parallelisms are also found in the heterotype prophases by most investigators, but these parallelisms are interpreted in three different ways.

(I) Although the parallelisms in the heterotype prophases may have identically the same appearance as the parallelisms of the somatic divisions, yet that in the heterotype division each side of the parallelism has a different origin to the other side, and each represents a whole somatic chromosome.

(2) That the parallelism in the heterotype prophases must be considered homologous with the parallelism of the somatic prophases, and consequently that in the heterotype prophases, as well as in the somatic prophases, each side of the parallelism has the same origin, that is to say that it arises from the same longitudinally split chromosome.

(3) That the parallelism found in the heterotype prophases has no real significance but is a mere coincidence.

The views of those who hold that the parallelism in the heterotype prophases is the pairing of homologous chromosomes will be taken first.

(I) Rosenberg (25) ( 1907 ) figured chromatin masses in the unreduced number in the heterotype prophases of Tanacetum vulgare which resembled those aggregations in the somatic divisions. These masses united in pairs in synapsis and each member of the 'Gamosomen-Paar' became a univalent chromosome. In Crepis virens, where the unreduced number of chromosomes is six and the reduced number is three, there are six prochromosomes in the somatic divisions; these six reappear in the early heterotype prophase and then unite in pairs, which, according to Rosenberg, must be regarded as the conjugation of two whole somatic chromosomes.

Overton (24) (I909) states: 'I am very strongly convinced that the arrangement of the prochromosomes in somatic and young germ cells is the same, that is, they are parallel in pairs,' and that 'the homologous parental elements are therefore associated in pairs when they enter the reconstructive stages of the germ nuclei'.

The Schreiners (28) have published a beautiful figure (Pl. 23, Fig. IO) of the 'Conjugation' of the chromosomes in the early heterotype prophase of Salamandra maculosa which exactly simulates the condensation of the chromosome in the somatic nuclei of the roots of Galtonia (Pls. LIX and LX, Figs. I9 and 20). There is the same irregular and partly beaded approximating sides, joined to the skeleton chromosomes on either side by delicate connexions.

Lundegardh's (16) drawings of the early heterotype prophases of Calendula officinalis closely resemble those of Galtonia, but he considers that the parallelisms represent the pairing of homologous chromosomes. 
In Trollius europaeus he has shown the alveolization of the chromosomes in the telophase of the last archesporial division, but unfortunately there is a rest between the telophase and the early heterotype prophase, so that it is impossible to trace the relationship between the portions of alveolized chromosomes of the telophase and the 'Gamosomen' of the prophase.

Grégoire (11) (I910) thus defines the difference between the somatic and heterotype prophase: 'Tandis que, dans une cinèse somatique, on voit le réseau quiescent se décomposer typiquement en des bandes alvéolaires ou en des tractus qui, par un mouvement de concentration, se transforment en chromosomes homogènes définitifs, ici (stades préspirématiques) au contraire, il se forme aux dépens du réseau.... un ensemble de filaments minces généralement assez long.' Further, that in the pollen mother-cells of Allium 'le passage du stade réseau au stade leptotène se fait par l'intermédiaire de bandes chromosomiques alvéolisées analogues à celles qui marquent la première origine des chromosomes somatiques, et que c'est de la transformation de ces bandes que résultent les filaments minces par un processus analogue à celui que l'on retrouve dans les cinèses somatiques. ... Il n'y a donc pas de doute, à notre avis, que chaque filament mince ne soit l'homologue d'un chromosome.' From these quotations it is clear that Grégoire, in the somatic prophases, considers each 'filament mince' to be the longitudinal half of a somatic chromosome, whilst in the heterotype prophases he considers each 'filament mince' to be a whole somatic chromosome. Grégoire perhaps makes insufficient allowance for the concentration of each univalent chromosome in the heterotype prophase which plays such a prominent part in the formation of the chromosomes in the somatic divisions. ${ }^{1}$

(2) One of the chief upholders of the opposed view that the parallelism in the heterotype prophases may possibly be the longitudinally split halves of the same chromosome is Häcker (12). He says: ' Ob nun freilich diese paarige Anordnung der präsynaptischen Chromosomenanlagen tatsächlicher auf eine Aneinanderlegung ursprünglich selbstständiger Elemente zurückzuführen ist, das scheint mir angesichts der grossen Schwierigkeiten, welche die folgende Synapsis-Phase der Analyse darbietet, noch nicht mit Sicherheit entschieden zu sein. Ich möchte vielmehr auf alle Fälle die Möglichkeit offen lassen, dass z. B. in den von Overton gegebenen Bildern, nicht eine Chromosomenpaarung im Sinne Strasburger's, sondern die Anlage eines frühzeitig gespaltenen Spirems im ursprünglichen, von Flemming (5) angenommenen Sinne vorliegt.'

Meves $(19,20)(1907,1908)$ finds that the parallel threads of the somatic and heterotype prophases are so closely similar that they must bear the same interpretation. Moreover, he considers that the threads are too thick

${ }^{1}$ Since this communication has gone to the printers another paper on prophases has been published, entitled: Kerndeeling en Synapsis bij Spinacia oleracea, L., by Theodor J. Stomps, Amsterdam, I910, pp. I-I62. 
and numerous, and the space of the nucleus too limited, to allow of the threads running parallel to one another throughout their length. $\mathrm{He}$ maintains that this is a physical impossibility, and that this impossibility is increased by the anastomosis amongst the threads themselves. If the parallelisms do represent the pairing of homologous parental chromosomes, how is the parallelism in parthenogenetic eggs to be explained? (19) (I907).

Goldschmidt $(7,8)(1905,1908)$ has shown that in the heterotype prophases of Zoogonus mirus the chromatin becomes collected into a 'zweireihige Lagerung der Körnchen zum Teil schon eine Andeutung der spätern Längsspaltung zeigend'. These behave like ordinary somatic chromosomes and go on to the spindle showing their longitudinal fission. The reduction takes place at the homotype division; the somatic number of chromosomes, which is ten, segregates into two groups of five.

Such is the evidence of those who hold that the parallelisms of the heterotype prophases are in no way different from those of the somatic divisions, that is to say that the parallelisms of the heterotype divisions arise from the longitudinal fission of the same somatic chromosome and not the approximation of two different somatic chromosomes. If this view is the true one then the approximation of the chromosomes, which is a necessary act on account of the reduction, must either take place, as Overton (24) (I909) suggests, in the telophase of the last archesporial division, or, as many cytologists have thought, during synapsis, or during the hollow-spireme and second-contraction stages.

(3) Finally, there are those workers who do not believe in the existence of parallelism, as such, in the heterotype prophases, and when it does occur they consider it to be a mere chance or coincidence. They base their arguments on the fact that there are often not only two threads running parallel to one another, but sometimes three or more. This anomaly may partly be explained by the fact that concentration for each somatic chromosome is often in the form of the drawing together of a netlike arrangement, as diagrammatically shown in the prophases of the nuclei of the root. Or it may be that where several threads run close to one another, concentration for the formation of the somatic chromosomes is proceeding simultaneously with the pairing of homologous chromosomes.

It seems only possible to settle this difficult question as to the homology of the parallelisms of the heterotype prophases by tracing their origin from the telophase of the preceding last archesporial division, and in order to do that it is essential to secure material in which there is no 'rest' between the premeiotic and meiotic divisions. There is much evidence to show that the parallelisms of the somatic and of the heterotype prophases have the same outward appearance, so that it is only by studying their origin that the truth as to their significance can be arrived at. 
Another suljject of discussion amongst cytologists is the question as to the origin of the univalent chromosomes which make up each bivalent pair in the heterotype prophases. One school contends that the chromosomes are arranged side by side in the spireme (11) (I9I0), the other that they are joined end to end (4) (1905).

In Galtonia the univalent chromosomes finally arise by a splitting apart of the thick bivalent segments, but these bivalent segments are composed of two primary distinct lengths of univalent spireme which conceivably may have joined during synapsis, although there is no direct evidence of this, but certainly become definitely approximated during the hollow-spireme and second-contraction stages.

As there is so much variety in the spireme as it comes out of synapsis, a variety apparent both in the thickness and in the arrangement of its loops and strands, and as the presence of anastomosis certifies that the arrangement and pairing of the homologous chromosomes cannot yet be in order, it seems possible that as long as the homologous chromosomes do pair eventually, it does not signify when they pair or in what manner they are joined. The important point which Galtonia demonstrates is that its spireme is univalent. Whether these univalent strands join with their homologous pairs telosynaptically or parasynaptically, or by any other intermediate method between these two extremes, resolves itself merely into a question of non-essential detail.

Lastly, the varied character and the great inequality shown by the nuclei of Galtonia throughout all the division figures must once more be emphasized. There is no 'cut and dried' definite arrangement; it cannot possibly be stated a priori that the formation of each individual chromosome is arrived at by some one particular method. The elaborations and intricacies are endless, and all that can be said is that the course of events appear to trend in some one direction, and that finally the same goal is reached, though the method actually pursued may be subject to great variation.

\section{SUMMARY.}

I. The chromosomes in the somatic and premeiotic divisions are formed from the telophase of the preceding division by an alveolization of the chromosomes and partial separation of the two sides, followed by a reconcentration of the same.

2. The parallel threads and portions of linin present in the early heterotype prophases are homologous with those in the somatic and premeiotic prophases. They are the remains of the alveolized portions of the chromosomes of the telophase of the last premeiotic division. There is no rest between the premeiotic and meiotic divisions. It is believed that during synapsis the parallelisms concentrate to form whole, or portions of whole, somatic chromosomes. The spireme as it comes out of synapsis is 
univalent in character, the longitudinal fission in its substance being homologous with that of the presynaptic stages, and consequently with that of the somatic prophases. The univalent homologous lengths of spireme may have joined end to end, or be partially united during synapsis, but it is not until the hollow spireme and second contraction that the pairing and fusion of the univalent chromosomes to form the bivalent segments are completed. As the bivalent chromosome segments come out of second contraction, they split apart into the two univalent chromosomes. At the homotype division these univalent chromosomes split longitudinally.

3. 'Crystalline' structures are present in the nuclei of the outer two or three rows of cells of the roots.

4. 'Chromatic' bodies are given off from the nucleus during the presynaptic, synaptic, and hollow-spireme stages.

In conclusion I wish to express my grateful thanks to Professor J. Bretland Farmer, F.R.S., for the constant and valuable help, advice, and criticism that he has given me throughout the course of this work.

\section{BIBLIOGRAPHY.}

1. Davis, B. M. ('09) : Pollen Development of Oenothera grandiflora. Ann. of Bot., xxiii, No. 92, Oct., pp. $55 \mathrm{I}-7 \mathrm{I}$.

2. Derschau, M. von ('09) : Beiträge zur pflanzlichen Mitose: Centren, Blepharoplasten. Pringsh. Jahrb. wiss. Bot., Leipzig, xlvi, I. Heft, pp. 103-1 7 .

3. Digby, L. ('09): Observations on Chromatin Bodies. Ann. of Bot., xxiii, No. 9r, July, pp. $49 \mathrm{I}-5 \mathrm{O} 2$.

4. Farmer, J. B., and Moore, J. E. S. ('05): On the Meiotic Phase (Reduction Divisions) in Animals and Plants. Quart. Journ. Micr. Sc., xlviii, Part 4, Feb., pp. 489-557.

5. Farmer, J. B., and Shove, D. ('05): On the Structure and Development of the Somatic and Heterotype Chromosomes of Tradescantia virginica. Quart. Journ. Micr. Sc., xlviii, Part 4, Feb., pp. 559-69.

6. Flemming, W. ('87): Neue Beiträge zur Kenntniss der Zelle. Archiv für mikroskop. Anat., Bonn, xxix, pp. 389-463.

7. Goldschmidt, R. ('05): Eireifung, Befruchtung und Embryonalentwicklung des Zoogonus mirus, Lss. Zool. Jahrb., Jena, xxi, pp. 607-54.

8. ('08): Die Chromatinreifung der Geschlechtszellen des Zoogonus mirus, Lss., und der Primärtypus der Reduktion. Arch. f. Zellforschung, Leipzig, ii, 2. Heft, Dec., pp. $34^{8}-70$.

9. Grégoire, V. ('06): L'Élément chromosomique dans les cellules végétales. La Cellule, xxiii, $2^{\mathrm{e}}$ fasc., pp. $3^{\mathrm{II}-53}$.

10. ('07): La Formation des Gemini hétérotypiques. La Cellule, xxiv, $2^{\mathrm{e}}$ fasc., pp. $369-420$.

11. Les Cinèses de maturation dans les Deux Règnes (2 ${ }^{\mathrm{e}}$ Mémoire). La Cellule, xxvi, $2^{\mathrm{e}}$ fasc., pp. $223^{2}-4^{22}$.

12. Ḧ̈CKer, V. ('07) : Die Chromosomen als angenommene Vererbungsträger. Ergebn. Fortschr. Zool., Jena, i, r. Heft, pp. I-1 36 .

13. Hyde, EdiTh ('09): The Reduction Division in the Anthers of Hyacinthus orientalis. Contributions from the Bot. Lab. of Ohio State University, xlvii, June, pp. 539-44. 
14. King, Helen D. ('09): The Spermatogenesis of Bufo lentiginosus. Amer. Journ. Anat., vii, No. 3 , Nov., $345^{-87}$.

15. Leitgeb, H. ('88): Krystalloide in Zellkernen. Mitt. aus dem Bot. Inst. zu Graz, Jena, pp. $115^{-22}$.

16. Lundegardi, H. ('09) : Utber Reduktionsteilung in den Pollen-Mutterzellen einiger dicotylen Pflanzen. Sv. Bot. Tids., Stockholm, iii, I. Heft, pp. 78-1 25.

17. Maréchal, J., et De Saedeleer, A. ('09): Le premier développement de l'Ovocyte chez les Rajides. La Cellule, xxvi, ${ }^{\text {er }}$ fasc., pp. $7-24$.

18. Merriman, Mabel L. ('04): Vegetative Cell Division in Allium. Bot. Gaz., xxxvii, No. 3, March, pp. $178-207$.

19. Meves, F. ('07): Spermatocytenteilungen bei der Honigbiene, nebst Bemerkungen über Chromatinreduktion. Arch. f. mikr. Anat., lxx, 3. Heft, Juli, pp. 4I4-9I.

20. ('08): Es gibt keine parallele Konjugation der Chromosomen. Archiv f. Zellforsch., Leipzig, i, 4. Heft, pp. 61 2-I 9 .

21. Miyake, K. ('05): Über Reduktionsteilung in den Pollenmutterzellen einiger Monokotylen. Pringsh. Jahrb. wiss Bot., Leipzig, xlii, pp. 83-120.

22. Mottier, D. M. ('07): The Development of the Heterotypic Chromosomes in Pollen Mothercells. Ann. of Bot., xxi, No. 83, July, pp. 309-47.

23. Overton, J. B. ('05): Über Reduktionsteilung in den Pollenmutterzellen einiger Dikotylen. Pringsh. Jahrb. wiss Bot., Leipzig, xlii, I. Heft, pp. I 2 I-53.

24. - ('09): On the Organization of the Nuclei in the Pollen Mother-cells of certain Plants with especial Reference to the Permanence of the Chromosomes. Ann. of Bot., xxiii, No. 89, Jan., pp. I9-61.

25. Rosenberg, O. ('07) : Zur Kenntniss der präsynaptischen Entwicklungsphasen der Reduktionsteilung. Sv. Bot. Tids., Stockholm, i, 4. Heft, pp. 398-410.

26. ('09): Zur Kenntniss von den Tetradenteilungen der Compositen. Sv. Bot. Tids., Stockholm, iii, I. Heft, pp. 64-78.

27. ('09) : Über den Bau des Ruhekerns. Sv. Bot. Tids., Stockholm, iii, 2. Heft, pp. $163-73$.

28. Schreiner, A. und K. E. ('07) : Neue Studien über die Chromatinreifung der Geschlechtszellen. Arch. Biol. Liége, xxii, fasc. 3 and 4 , Feb., pp. 419-92.

29. Stevens, N. M. ('06): Studies in Spermatogenesis (Part II): A Comparative Study of the Heterochromosomes in certain Species of Coleoptera, Hemiptera, and Lepidoptera, with especial Reference to Sex Determination. Carnegie Institution of Washington, Oct., pp. 33-74.

30. Strasburger, E. ('04) : Über Reduktionsteilung. Sitzungsber. Königl. Preuss. Akad. Wiss. zu Berlin, xviii, pp. $5^{8} 7-614$.

31 ('05): Typische und allotypische Kernteilung. Prings. Jahrb. wiss. Bot., Leipzig, xlii, pp. I-7I.

32. ( 07$)$ : Ủber die Individualität der Chromosomen und die PfropfhybridenFrage. Prings. Jahrb. wiss. Bot., Leipzig, xliv, 3. Heft, pp. $4^{82-555}$.

33. Walker, C. E., and Tozer, F. M. ('09) : Observations on the History and possible Function of the Nucleoli in the Vegetative Cells of various Animals and Plants. Quart. Journ. Exper. Physiol., ii, No. 2, March, pp. 187-200.

34. Wilson, E. B. ('05): Studies on Chromosomes. I. The Behaviour of the Idiochromosomes in Hemiptera. Journ. of Exp. Zool., ii, No. 3, Aug., pp. 37I-405.

35. ('05): Studies on Chromosomes. II. The Paired Microchromosomes, Idiochromosomes, and Heterotropic Chromosomes in Hemiptera. Journ. of Exp. Zool., ii, No. 4 , Nov., pp. $507-45$.

36. Zimmermann, A. ('93): Beiträge zur Morphologie und Physiologie der Pflanzenzelle, i, Tübingen. 


\section{EXPLANATION OF PLATES LIX-LXIII.}

\section{Illustrating Miss Digby's paper on the Nuclear Divisions of Galtonia candicans.}

All the figures were drawn with the camera lucida under a $2 \mathrm{~mm}$. apochr. Hom. imm. Zeiss, N.A. I 40 with comp. oc. $18 . \times 2250$.

Figs. I-I 4. Somatic divisions in the root.

Figs. 15 and 16 . Divisions in the wall of the ovary.

Figs. $17-27$. Premeiotic divisions of archesporium.

Figs. 28 and 29. 'Crystalline' structures, and nucleolar division in root.

Figs. 30 and 3 I. Telophase of last archesporial division.

Fig. 32. Prophase in tapetum.

Figs. 33-73. Heterotype divisions.

Figs. 74-83. Homotype divisions.

\section{PLATE LIX.}

Fig. I. Root. Chromosomes collecting on the equatorial plate. Note the different degrees of longitudinal fission. The nucleolus has been thrown out.

Fig. 2. Polar view of equatorial plate. The small chromosomes are arranged in the centre.

Fig. 3. The chromosomes are beginning to split on the equatorial plate.

Fig. 4. The chromosomes have nearly separated. The small chromosomes are in advance of the others.

Fig. 5. The chromosomes have separated. Note the fine connexions that join them.

Fig. 6 A. Telophase. Showing the alveolization of the chromosomes and the consequent parallelism of their sides.

Fig. 6 в. Late telophase which has passed into the 'resting' stage. The linin has broken up into small rounded particles.

Fig. 7. 'Resting' stage. The linin network is confined to the periphery of the nucleus.

Fig. 8. Early prophase showing the parallel rows of linin granules. Condensing to form concentrated portions of ' chromosome bands'.

Fig. 9. Still further approximation of the paired linin strands. Fine connexions join the strands to one another.

Fig. Io. Slightly later stage in the concentration of the strands. Note the alveolization in the strands, and the longitudinal fission which arose as the space between the condensing strands.

Fig. II. Nucleus showing uneven concentration of the linin resulting in a corkscrew-like spireme.

Fig. I2. Late prophase showing spireme segmented into chromosomes with most marked longitudinal fission.

Fig. I3. Definite chromosomes. The chromosome (V) has already split, forming a widely extended V. Note the fine connexions.

Fig. I 4. Longitudinally split chromosomes collecting in the centre of the nucleus. Cytoplasmic radiations have appeared prior to the formation of the spindle.

Fig. 15. Wall of ovary. Diaster.

Fig. 16. Late diaster; the chromosomes have lost their individuality.

Fig. I7. Archesporium. Telophase. A cell-plate is forming, the chromatin mass is beginning to loosen out.

Fig. 18. Polar view of a nuclens in telophase, showing the breaking up of the chromosomes, and the fragments united by fine connexions. somes.

Fig. 19. Superficial section of a nucleus in telophase, showing the alveolization of the chromo-

\section{PLATE LX.}

Fig. 20. Later telophase. The alveolized portions of chromosomes are breaking up into parallel rows of granules. 
Fig. 21. Still later telophase, in which the remains of some of the 'chromosome bands' are to be seen, whilst the others have broken up and have lost their identity. There is a clear space round the nucleolus.

Fig. 22. Very early prophase, showing the parallel arrangement of the linin as strands of beads, some strands having already concentrated into chromosome segments.

Figs. 23 and 24. Progressive stages in the concentration of the linin to form the chromosome segments.

Fig. 25. Still further concentration; the linin is now in the form of thickened masses, showing parallelisms in their sides.

Fig. 26. Late prophase, showing segmented spireme.

Fig. 27. Slightly later stage in which the spireme segments have thickened considerably. The segments are homogeneous.

Fig. 28. Root. 'Crystalline' structures in the nucleus. n., nucleus ; c. b., crystalline bodies; r., refractive dots.

Fig. 29. Division of nucleoli by constriction.

Fig. 30. Telophase of last archesporial division. There is the same alveolization of the chromosomes resulting in the formation of paired threads as in the telophases of somatic divisions.

Fig. 3I. Polar view of a nucleus in telophase of the last archesporial division.

Fig. 32. Tapetal nucleus in early prophase, showing parallelisms in its nuclear contents.

Fig. 33. Heterotype prophase. The telophase of the last archesporial division passes imperceptibly into the prophase of the heterotype division. The linin shows great irregularity in the size of its particles. Nute the parallelism resulting from the alveolization of the chromosome segments.

Fig. 34. Nucleus in which portions of the chromosomes show alveolization before the sides have separated.

Fig. 35. Superficial section of a nucleus in the same stage as Fig. 34 .

Figs. $3^{6}$ and 37. Show a still finer breaking up of the chromosomes, the sides of the alveolized chromosomes remaining in places as parallel beads or strands.

Fig. $38 \mathrm{~A}$. The linin is becoming concentrated into larger masses preparatory to going into synapsis.

Fig. $3^{8}$ в. Superficial section of the same stage, showing that, notwithstanding the contraction, the parallelism is still present.

Fig. 39 A. The massing of the linin increases.

Fig. 39 B. Superficial section of a nucleus at the same stage as Fig. $39 \mathrm{~A}$, showing the longitudinal fission.

\section{PLATE LXI.}

Fig. 40. Further massing of the nuclear contents, but parallelisms are still to be seen.

Fig. 4I. The nuclear contents are collecting at one side of the nucleus.

Fig. 42. Synapsis showing chromatin areas embedded in the linin substance. 'Chromatic' bodies are being extruded.

Fig. 43. Typical close synapsis, with extrusion of 'bodies'.

Fig. 44. Loosening of the synaptic knot; its substance is emerging in the form of thick loops.

Fig. 45. Some of the strands are beaded, and show longitudinal fission.

Fig. 46. Further loosening of the knot. The strands are beaded.

Fig. 47. Hollow spireme stage, in which the spireme is arranged in loops lying freely in the nuclear cavity.

Fig. 48. The loops are beginning to concentrate towards the centre of the nucleus. Note the conspicuous longitudinal fission, the varied thickness of the strands, and the anastomosis between the strands.

Fig. 49. Nucleus which is undergoing a more prolonged 'hollow-spireme' stage. The threads have straightened, they are irregular in thickness, and there is anastomosis between them.

Fig. 50. Further straightening of the spireme, which has now segmented.

Fig. 51. Commencement of the second contraction. The segments are collecting towards the centre; note the two lengths of spireme which are apparently joining end to end.

Fig. 52. Beginning of second contraction. In this case the nucleus is going into second contraction on emerging from synapsis. The sides of the loops are being drawn in parallel to one another, and in places they have joined side by side. 
Fig. 53. Further preparation for second contraction. The univalent portions uniting to form the bivalent strands.

Fig. 54. The segments are going into second contraction.

\section{PLATE LXII.}

Fig. 55. Second contraction. Those segments which are escaping show the separation of the two univalent chromosomes.

Fig. 56. Loosening of the second contraction. The loops exhibit longitudinal fission. A small pair of chromosomes have already separated from the contraction.

Fig. 57. The eight pairs of univalent chromosomes are seen to be splitting apart as they come out of second contraction.

Figs. $5^{8} \mathrm{~A}$ and $5^{8}$ в. Two sections throngh the same nucleus. In Fig. $5^{8} \mathrm{~A}$ the segments are still in masses, whilst in Fig. $5^{8}$ B they have begun to split apart into the univalent chromosomes.

Figs. $59 \mathrm{~A}$ and 59 B. Sections through the same nucleus, showing the splitting of the bivalent limbs. The eight pairs of chromosomes can be identified.

Fig. 6o. Slightly later stage, in which the chromosomes are becoming more concentrated. Note the longitudinal fission in the separate univalent chromosomes.

Fig. 61. Shows a looped bivalent chromosome, of which one side is concentrated, whilst the other is still in a beaded condition.

Fig. 62. Later stage in the concentration of the chromosomes.

Fig. 63. Nucleus with its chromosomes joined end to end like the links of a chain.

Fig. 64. Diakinesis. The nucleolus has fragmented.

Fig. 65. Chromosomes going on to the equatorial plate.

Fig. 66. Polar view of an equatorial plate.

Fig. 67. Chromosomes passing to the poles.

\section{PLATE LXIII.}

Fig. 68. Anaphase of the heterotype division. Each chromosome is split.

Fig. 69. Polar view of anaphase, showing the eight split chromosomes.

Fig. 70. Telophase in which the chromosomes have formed themselves into an indistinguishable mass and the alveolization is commencing.

Fig. 7r. Polar view of a nucleus in telophase, showing breaking up of the chromosomes and the origin of the paired threads and parallelisms.

Fig. 72. Telophase of first meiotic division.

Fig. 73. Further fragmentation of the chromosomes in the telophase. The remains of the spindle fibres are still visible.

Fig. 74. Homotype prophase, showing a reconcentration of the linin portions.

Fig. 75. The two nuclei elongate, and spindle fibres make their appearance. The nuclear contents become more and more concentrated to form the chromosome segments.

Fig. 76. Polar view of a nucleus in the same stage as Fig. 75 .

Fig. 77. Further concentration of the segments to form the chromosomes.

Fig. 78. Long loop-like chromosomes going on to the spindle.

Fig. 79. Equatorial plate of homotype division.

Fig. 80. The chromosomes are moving off to the poles.

Fig. 8I. Diaster of homotype division. masses.

Fig. 82. Telophase of tetrad nucleus, showing the breaking up of the chromosomes into parallel

Fig. 83. 'Resting' nucleus of the future pollen grain. The chromatin contents are in the form of granules, and parallelism is still visible. 

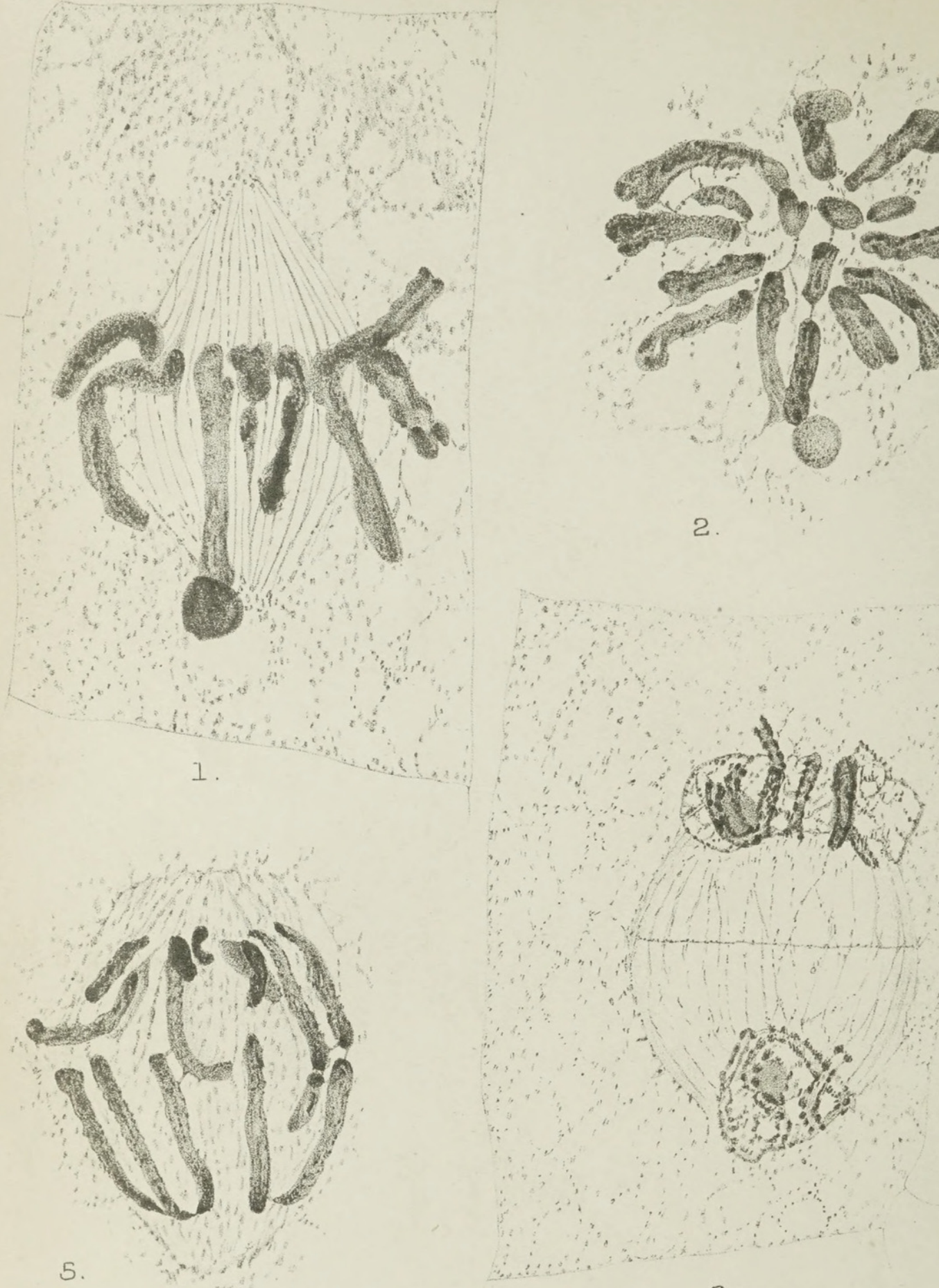

$6 a$
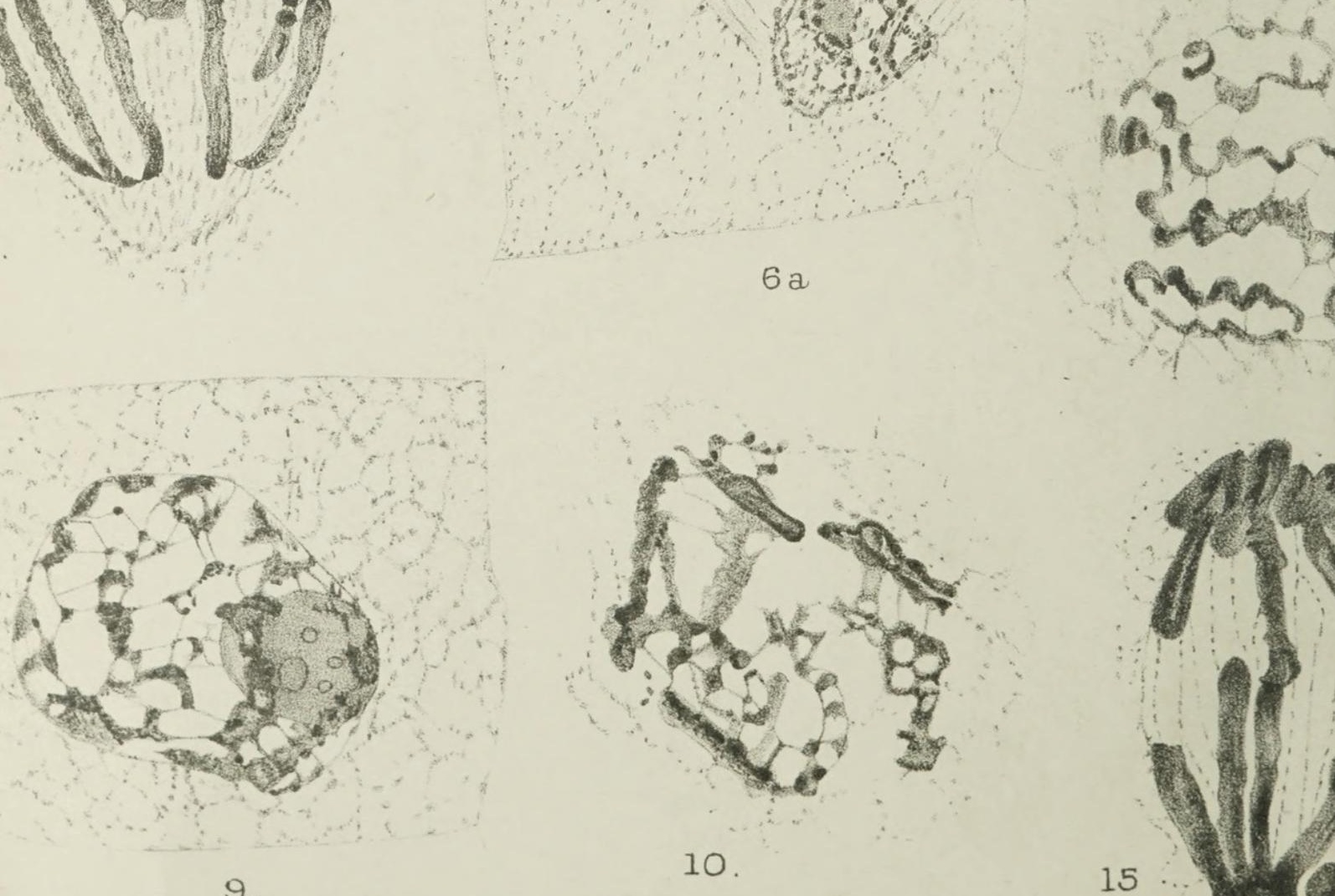

9.

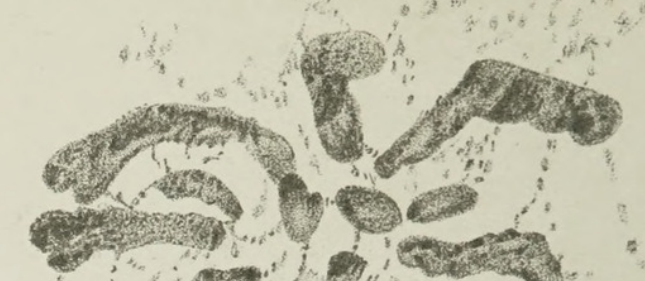

2

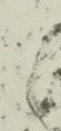

(3) 

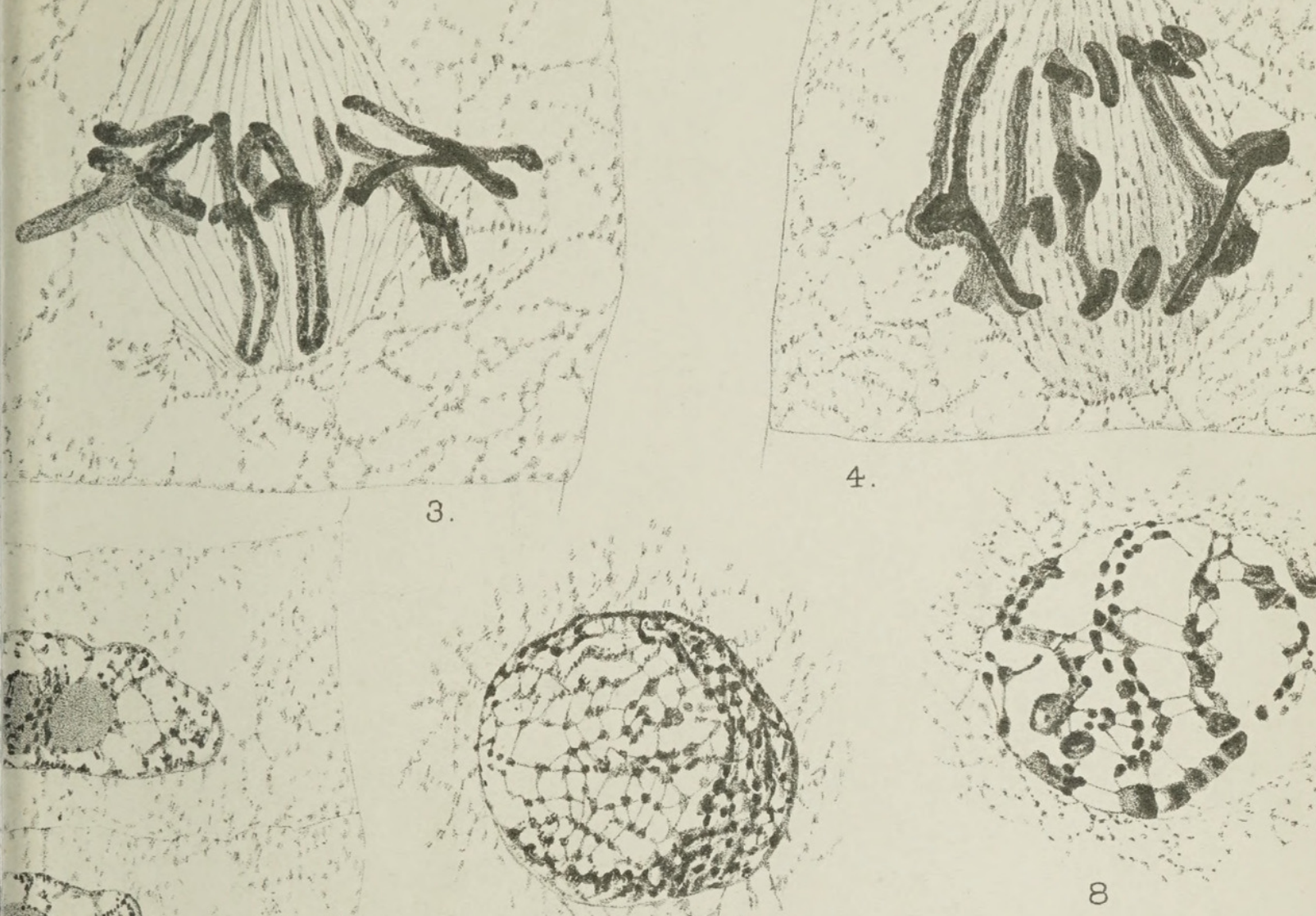

4
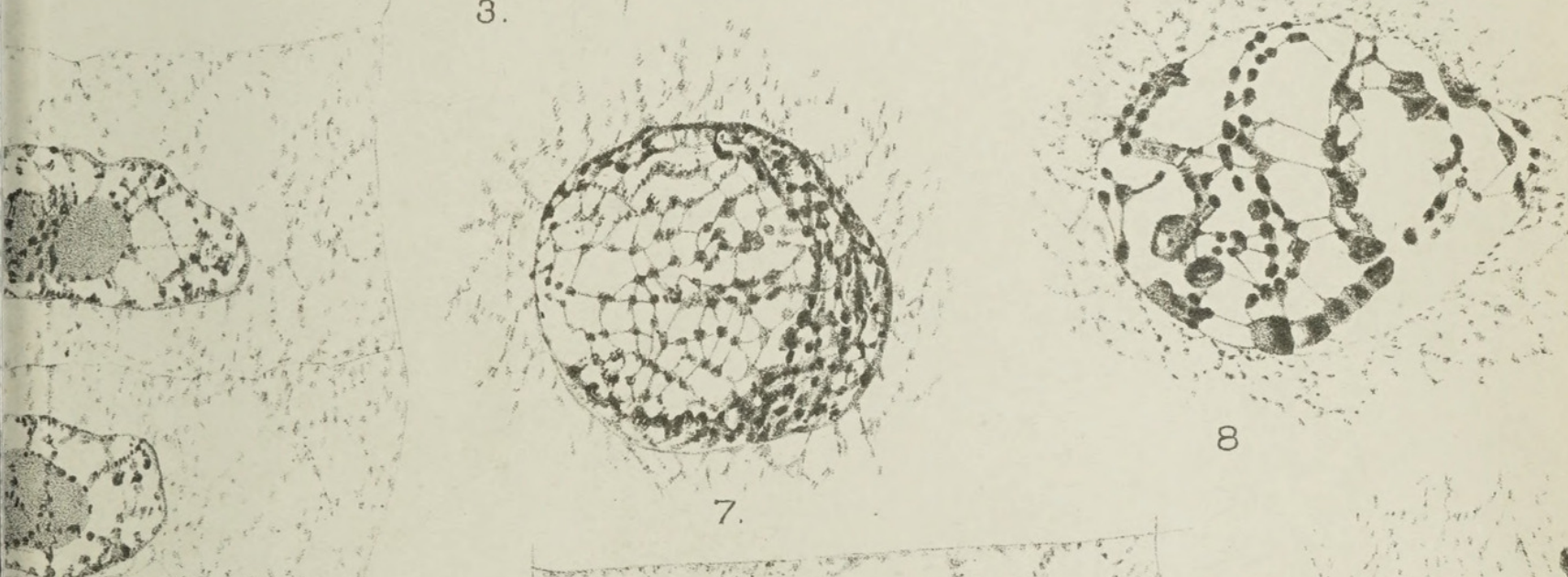

8

$6 \mathrm{~b}$
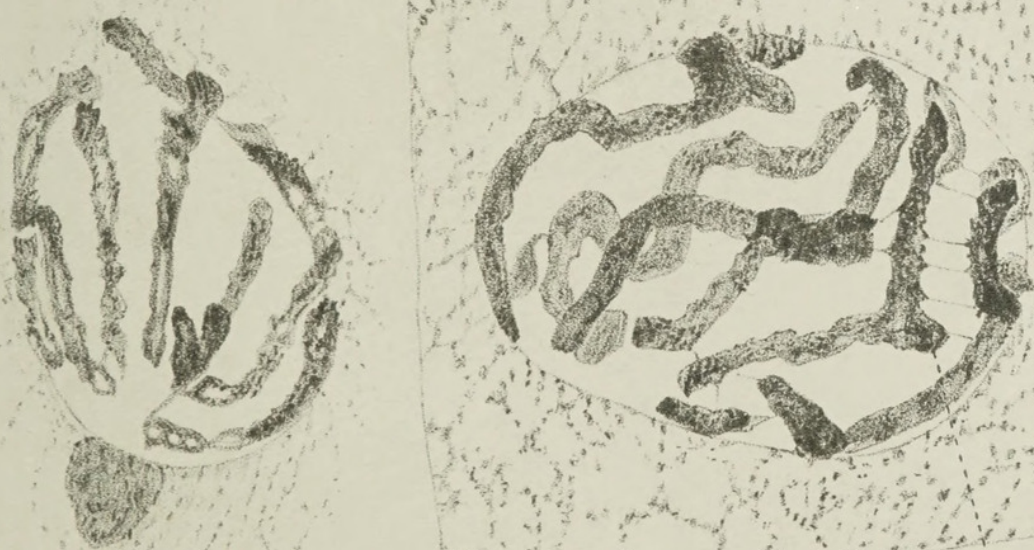

12.

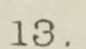

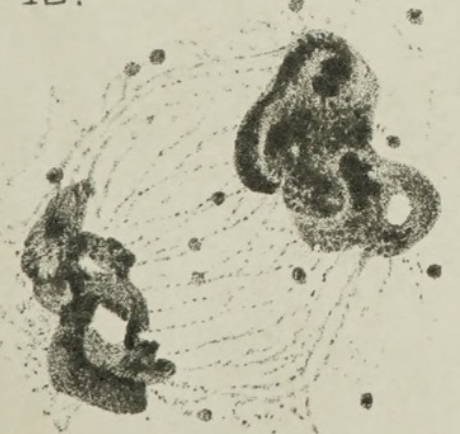

16

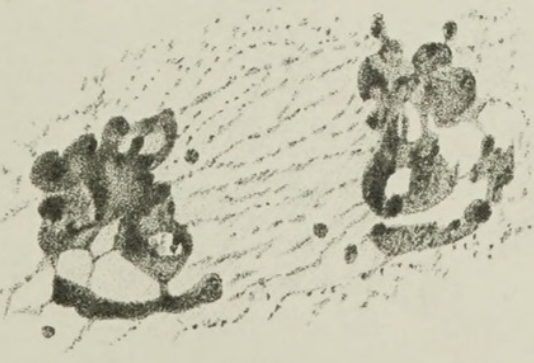

17.

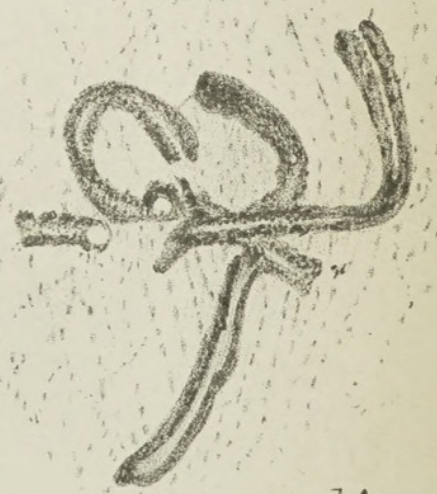

14
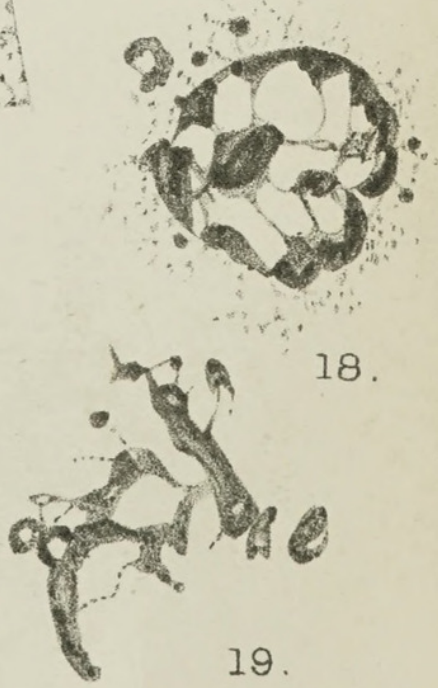
Annats of Botany,

20.

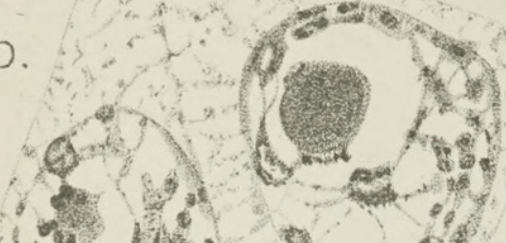

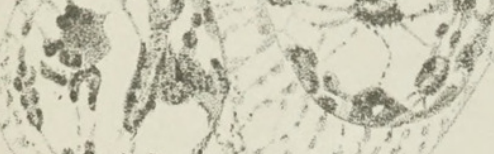
4. 35

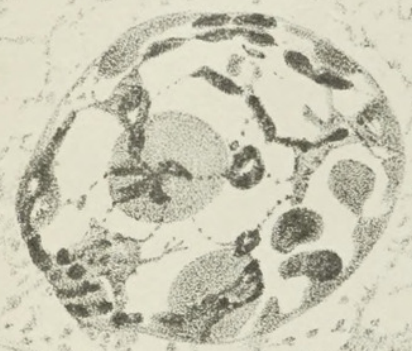

25.

30.
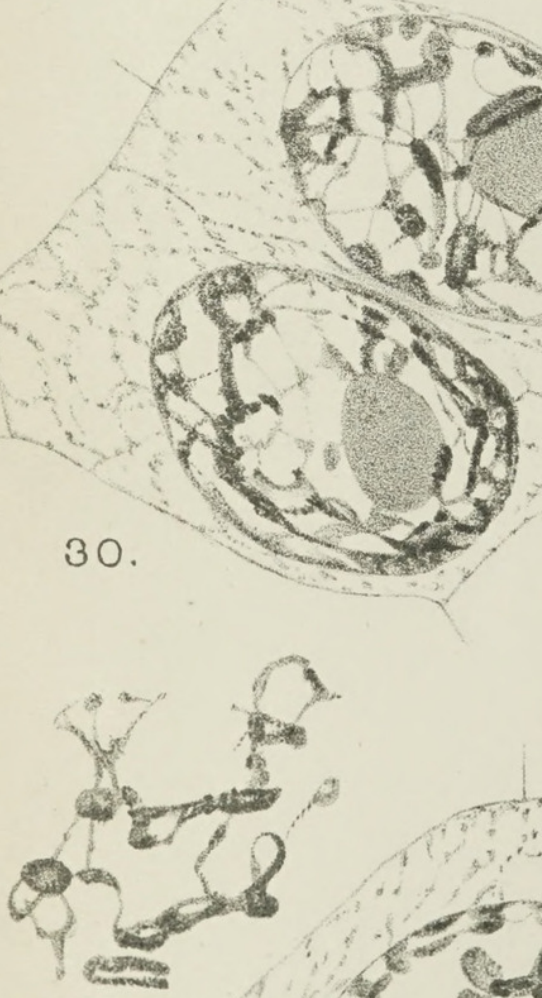

35.

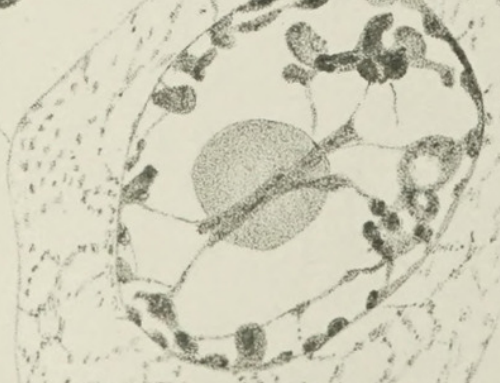

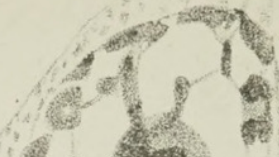

(1)

1.

(n)

21.

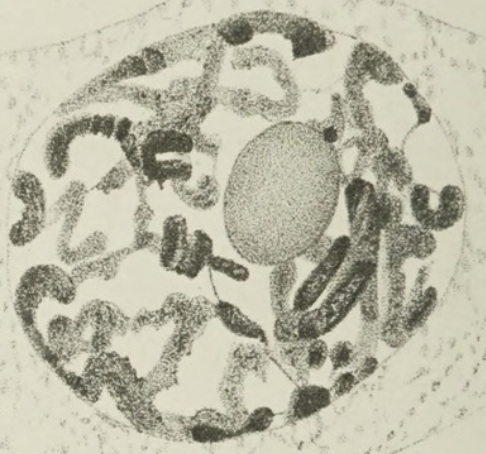

26.

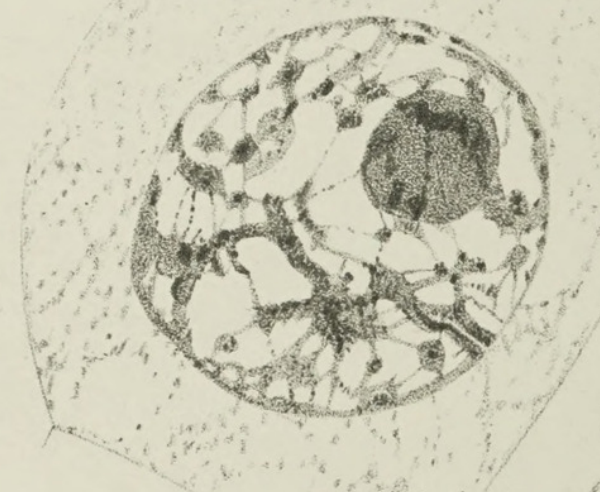

6

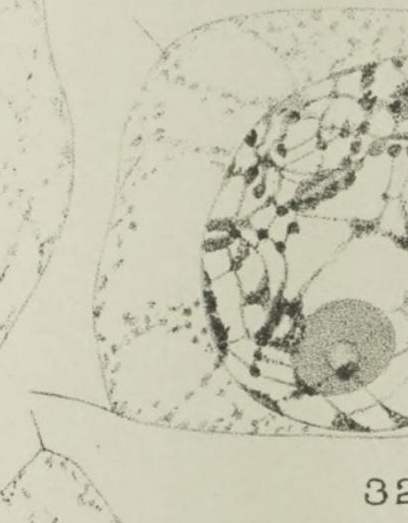

31.

36. 


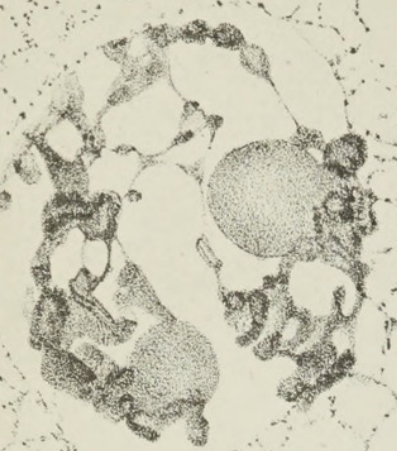

40

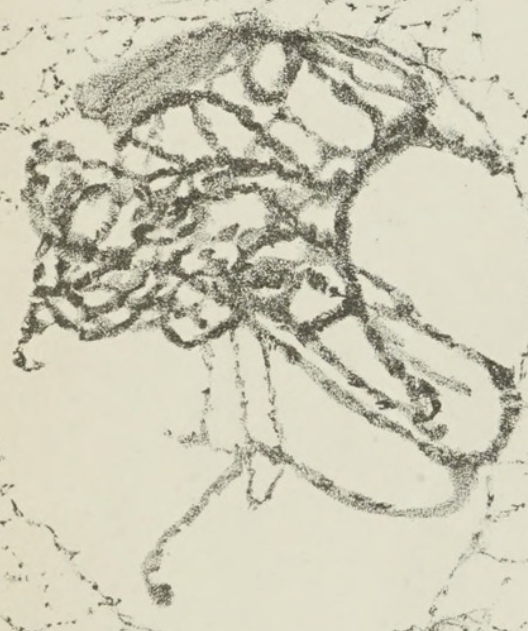

46.

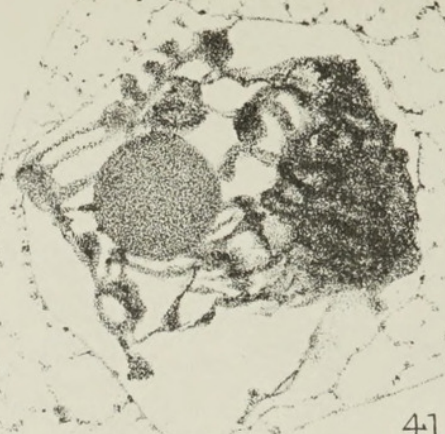

45.
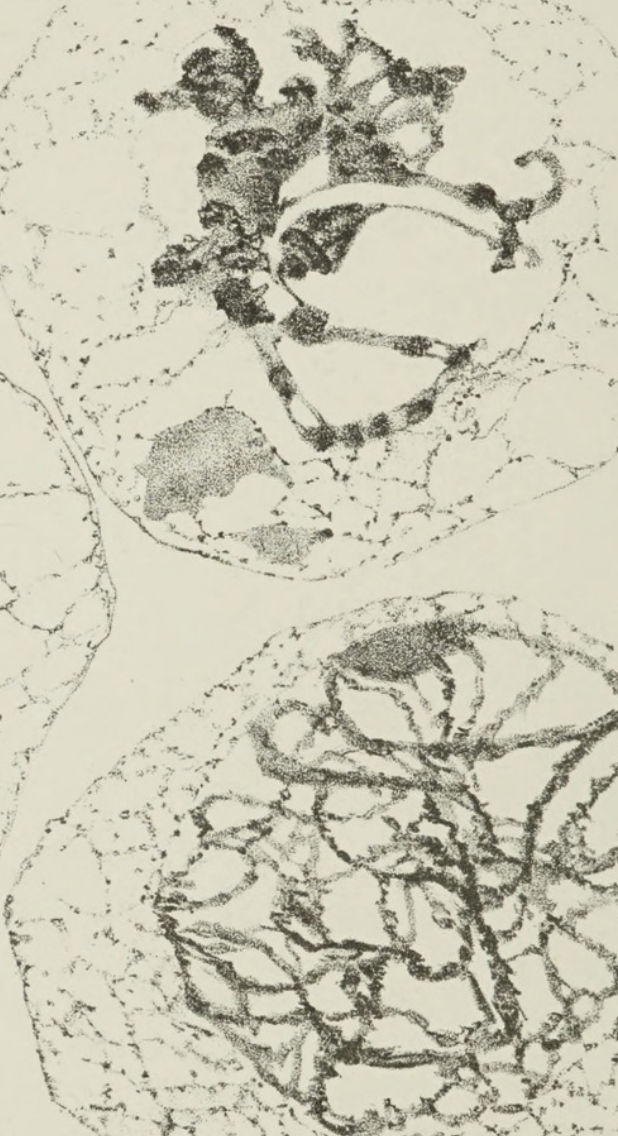

41.
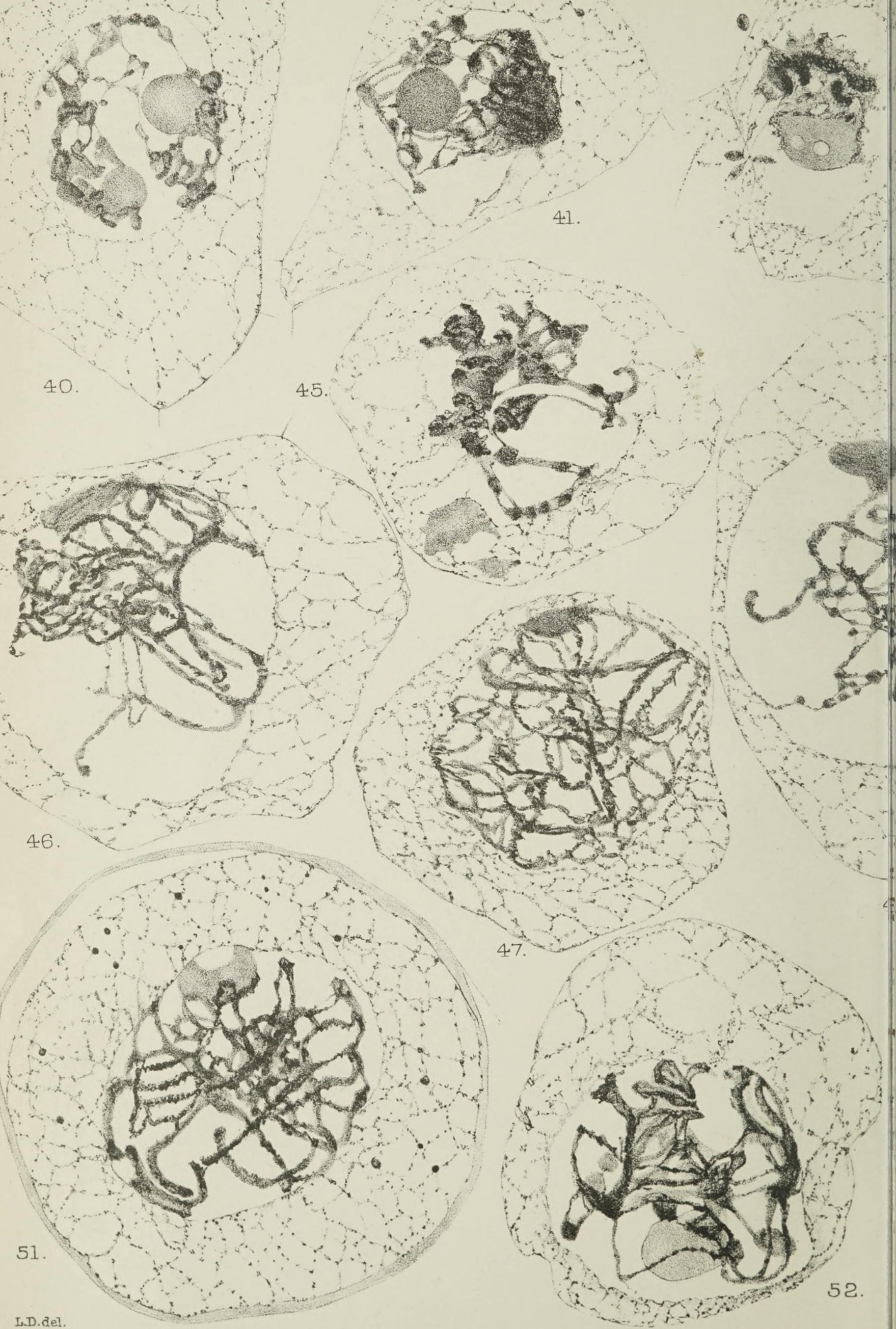
42.

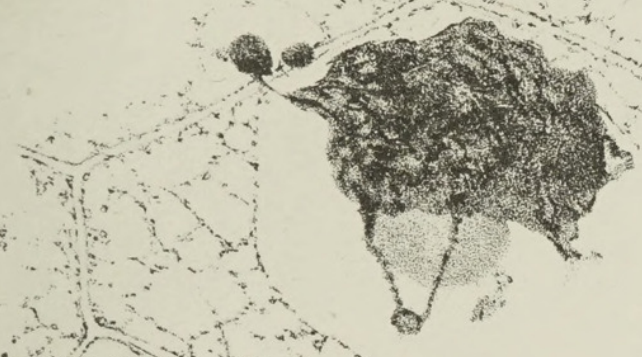

3. है

a

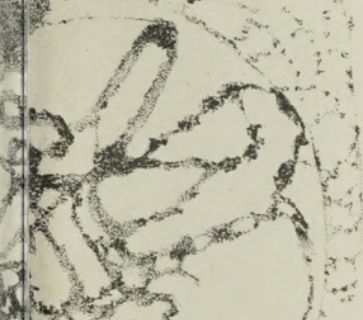

4
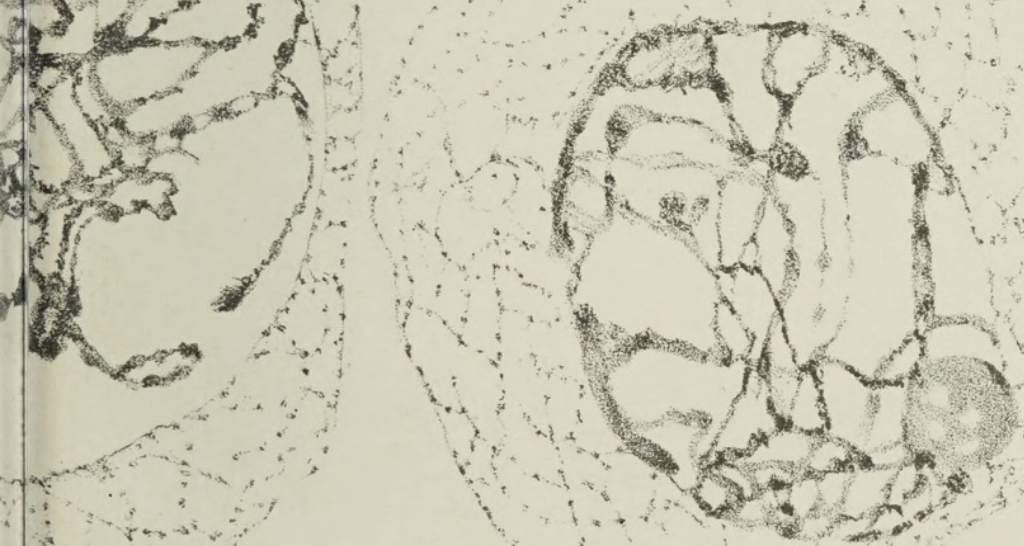

49.

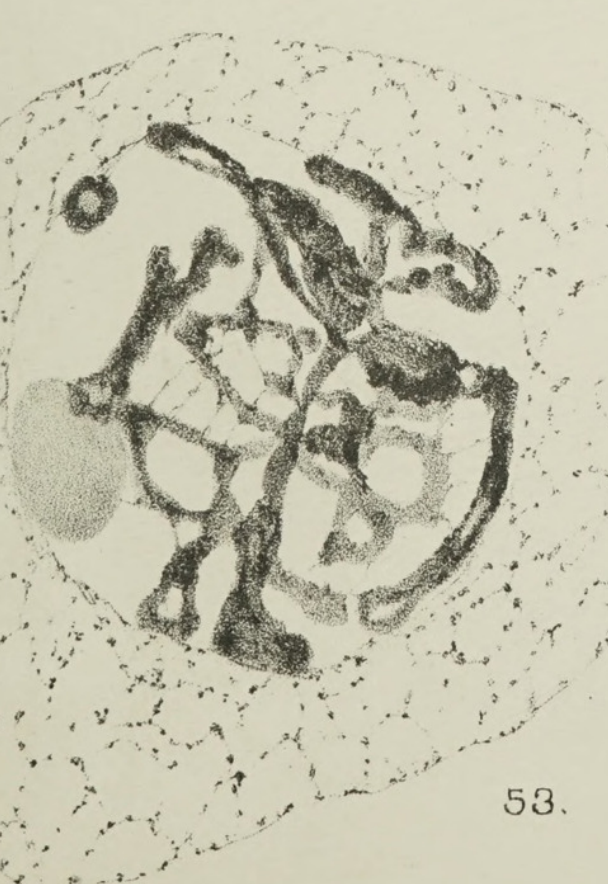

53.

$=$

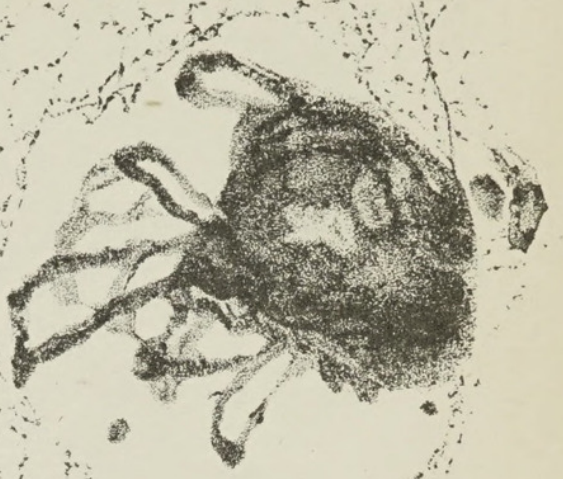

?

44

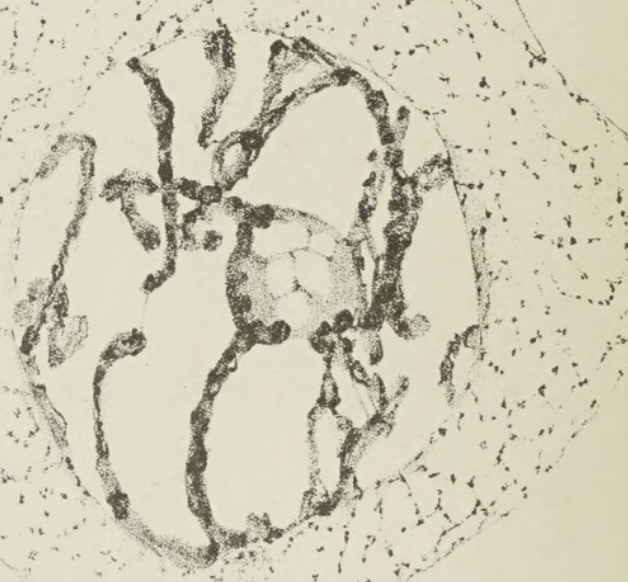

50.

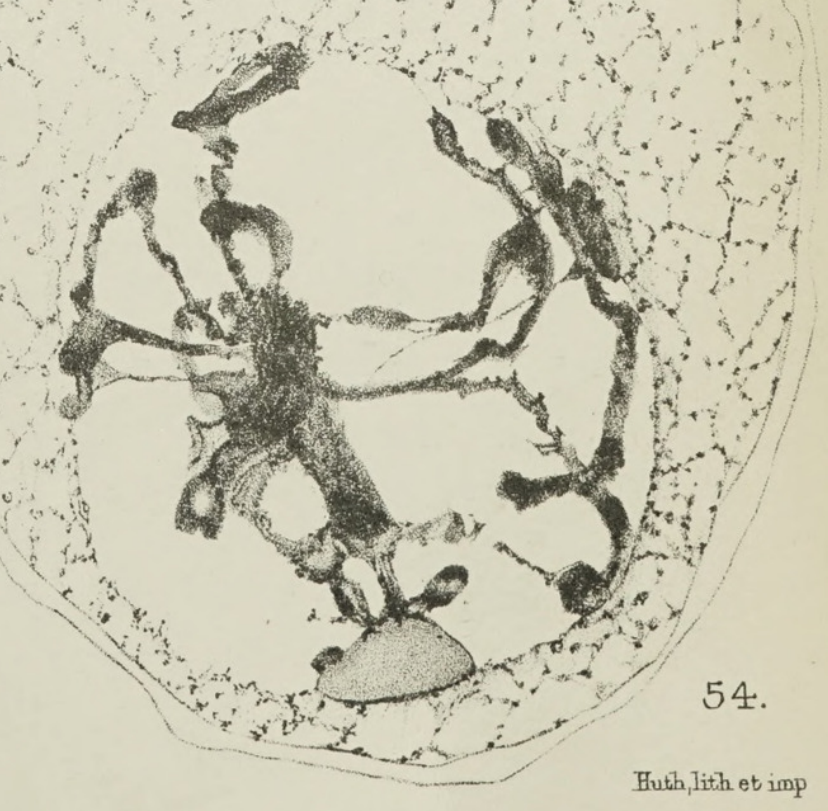



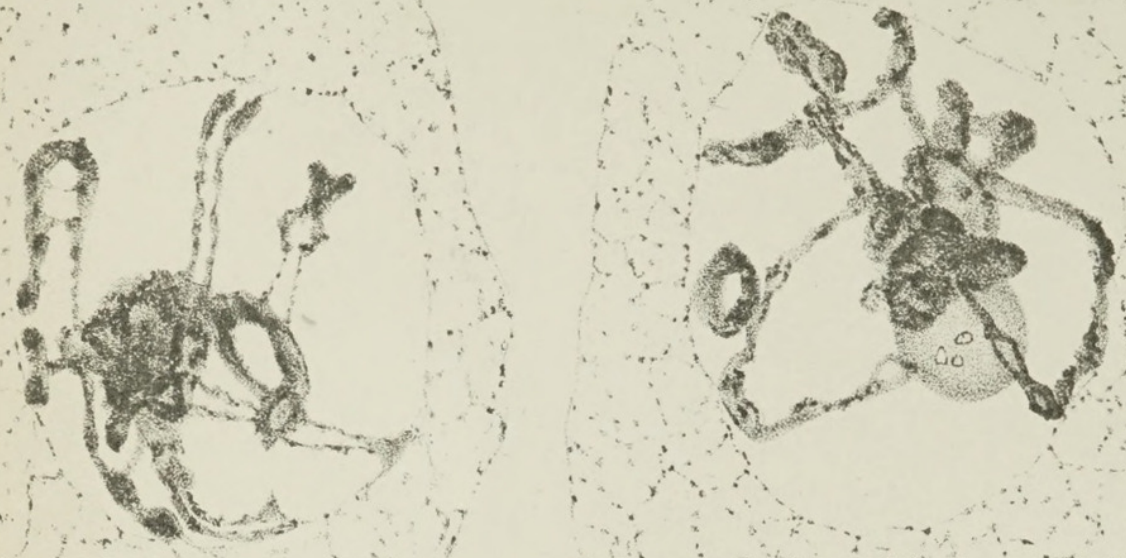

56.
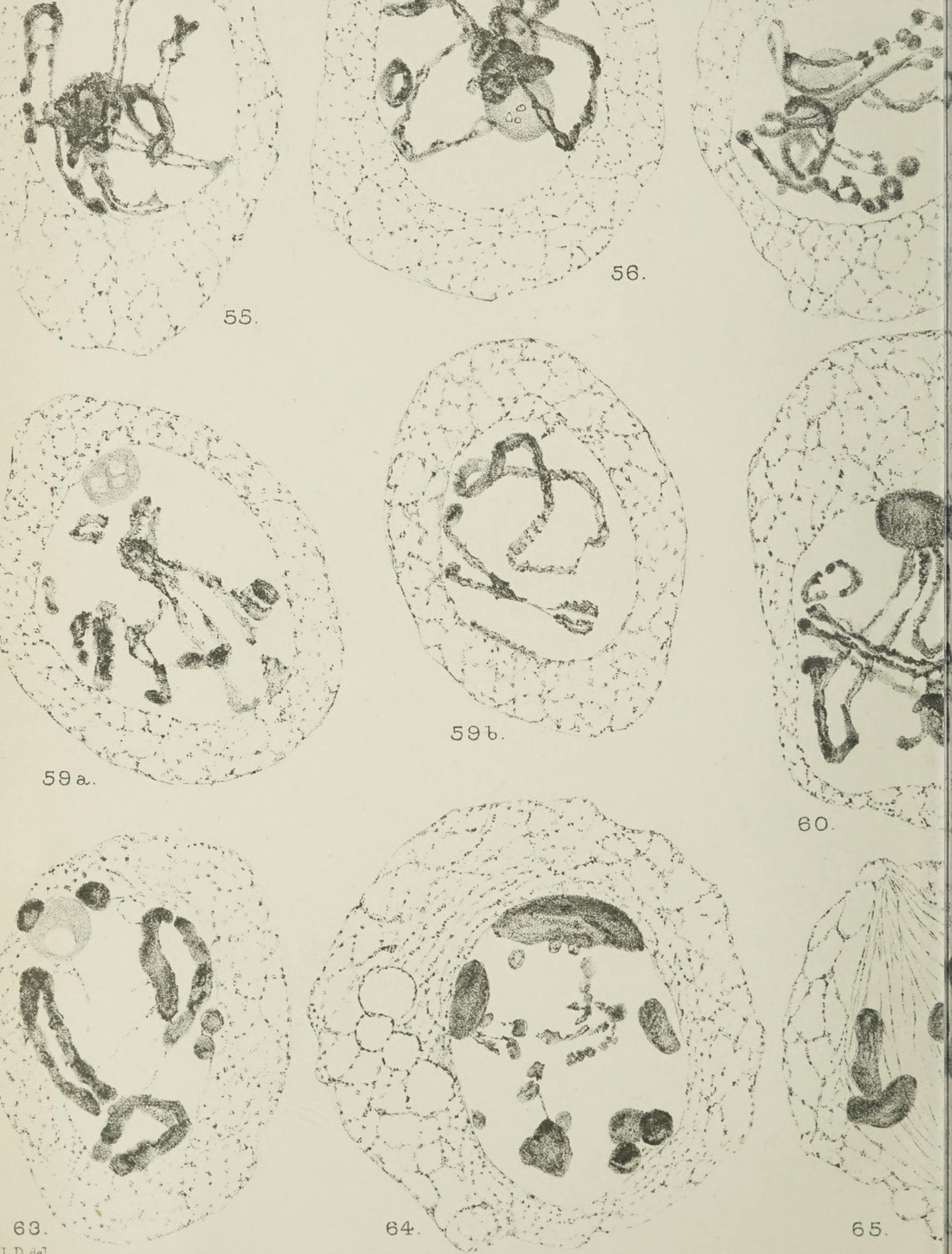

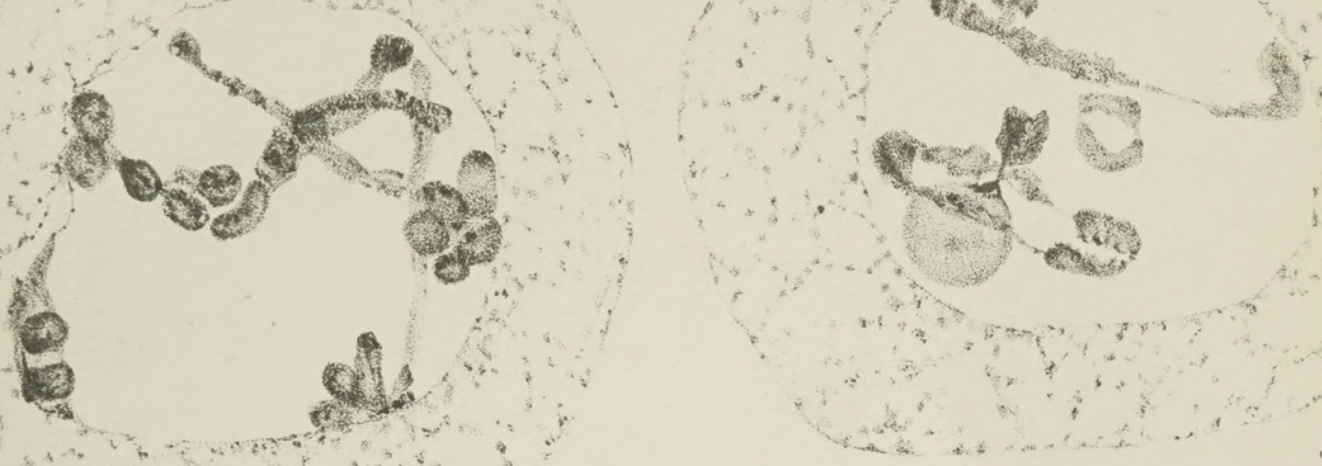

$58 \mathrm{~b}$. 
Annats of Botany,

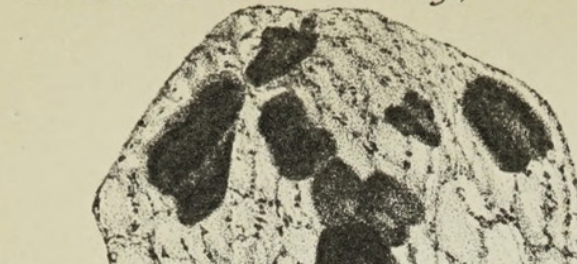

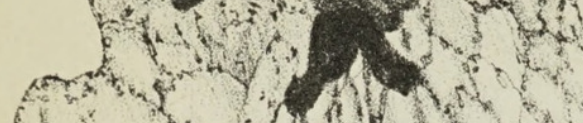

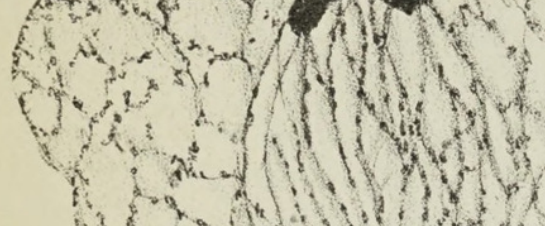
as
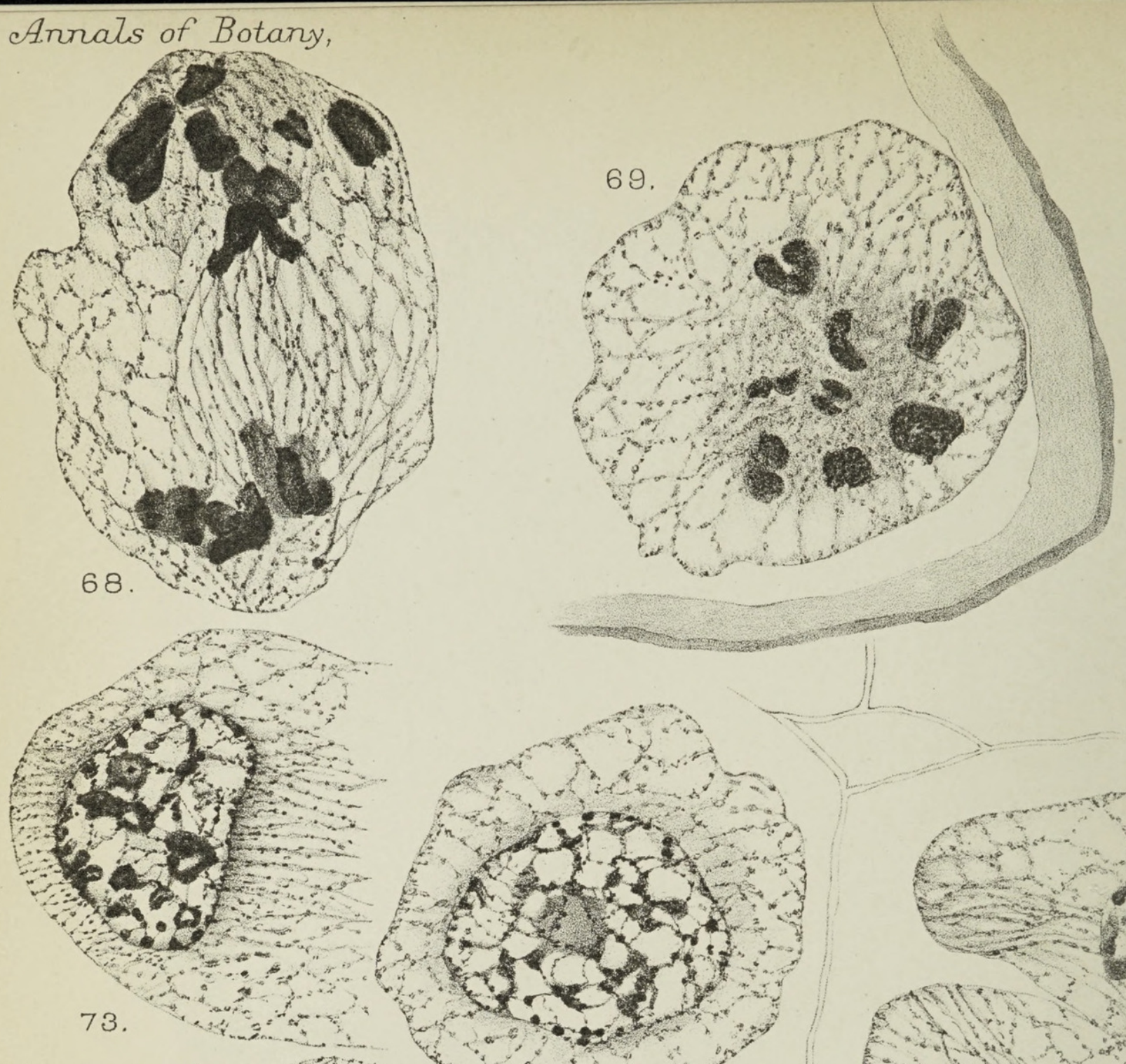

70.
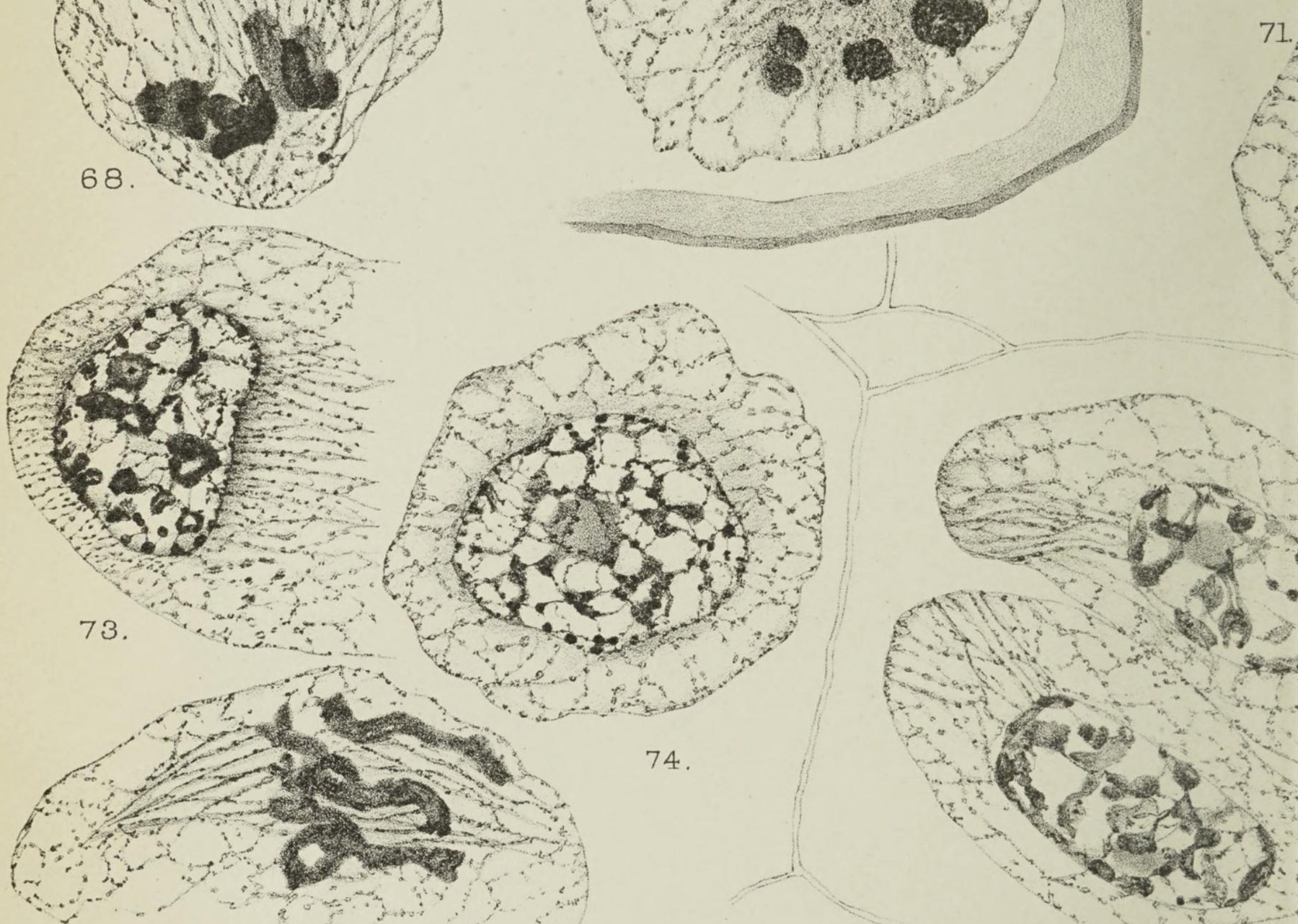

74.

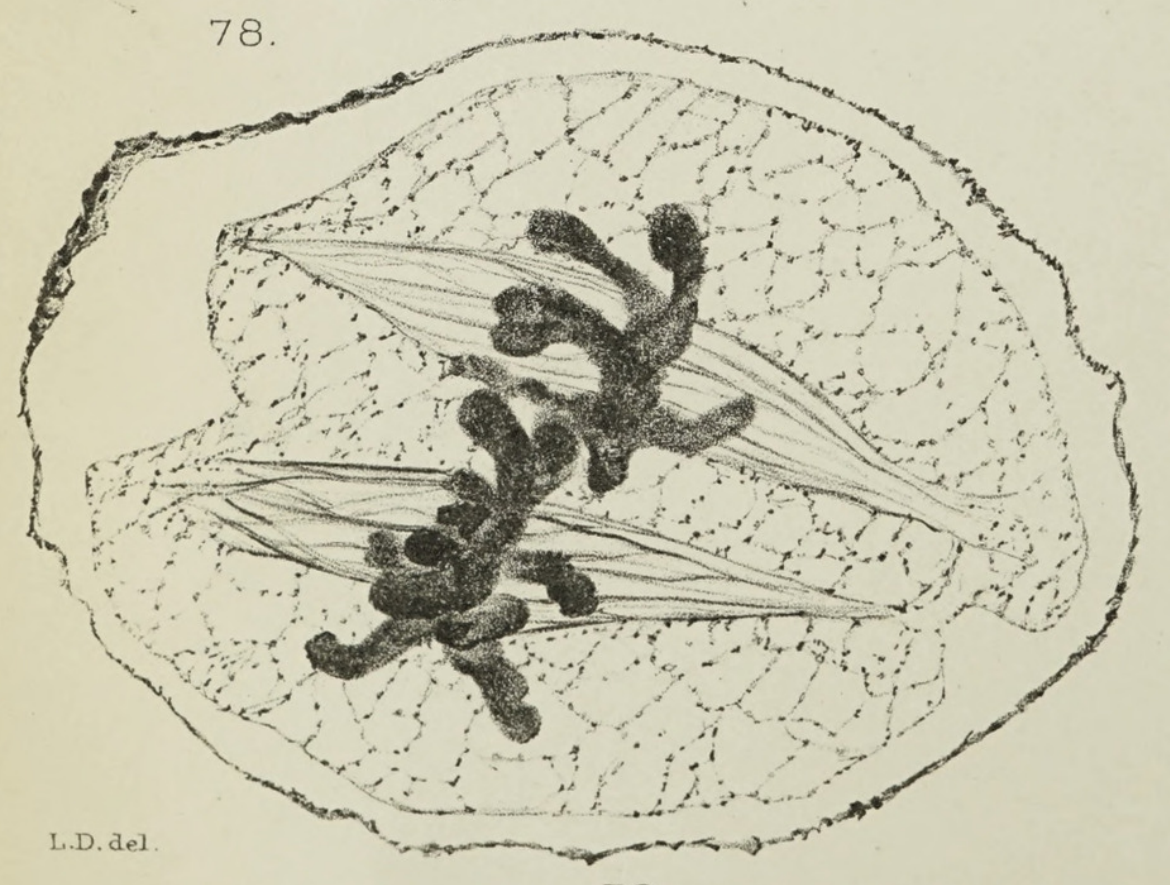

75.

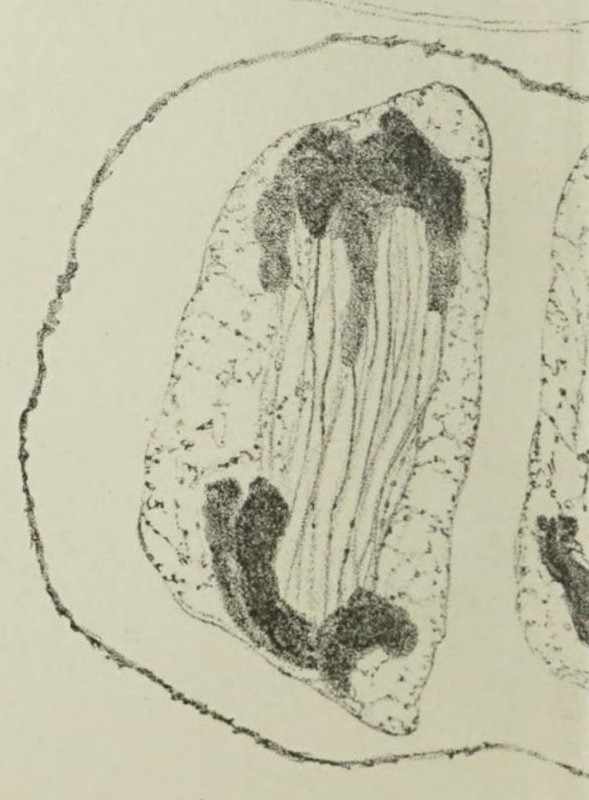

81.

DIGBY- NUCLEAR DIVISIONS IN GALTONIA. 


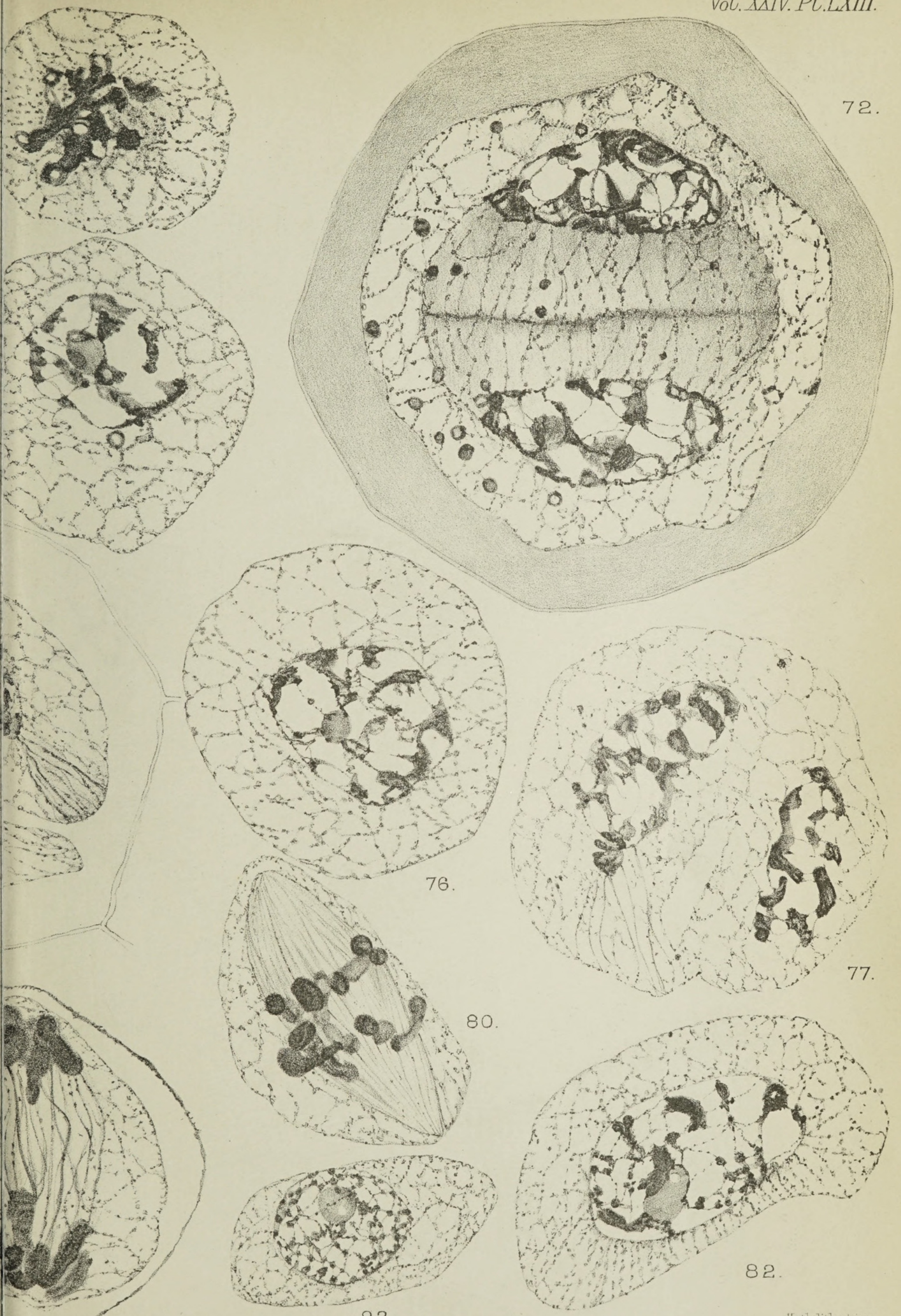




\section{$2 \mathrm{BHL}$ Biodiversity Heritage Library}

Digby, Lettice. 1910. "The somatic, premeiotic, and meiotic nuclear divisions of Galtonia candicans." Annals of botany 24, 727-757. https://doi.org/10.1093/oxfordjournals.aob.a089301.

View This Item Online: https://www.biodiversitylibrary.org/item/262605

DOI: https://doi.org/10.1093/oxfordjournals.aob.a089301

Permalink: https://www.biodiversitylibrary.org/partpdf/319809

\section{Holding Institution}

New York Botanical Garden, LuEsther T. Mertz Library

\section{Sponsored by}

BHL-SIL-FEDLINK

\section{Copyright \& Reuse}

Copyright Status: Public domain. The BHL considers that this work is no longer under copyright protection.

This document was created from content at the Biodiversity Heritage Library, the world's largest open access digital library for biodiversity literature and archives. Visit BHL at https://www.biodiversitylibrary.org. 